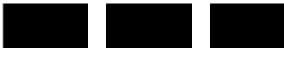 \\ DE
}

The WiLliam DAVIDSON INSTITUTE AT THE UNIVERSITY OF MICHIGAN BUSINESS SCHOOL

\section{What Makes Small Firms Grow? \\ Finance, Human Capital, Technical Assistance, and the Business Environment in Romania}

By: J. David Brown, John S. Earle and Dana Lup

William Davidson Institute Working Paper Number 702

May 2004 


\title{
What Makes Small Firms Grow? \\ Finance, Human Capital, Technical Assistance, and the Business Environment in Romania
}

\author{
J. David Brown \\ Heriot-Watt University \\ CEU Labor Project \\ John S. Earle* \\ Upjohn Institute for Employment Research \\ Central European University \\ Dana Lup \\ CEU Labor Project \\ University of Chicago
}

Revised: April 2004

Journal of Economic Literature classification numbers: M13, O16, O19, P26

Keywords: Small Firms, Entrepreneurship, Microfinance, Business Environment, Romania

Although the development of a new private sector is generally considered crucial to economic transition, there has been rather little empirical research on the determinants of startup firm growth. This paper uses panel data techniques to analyze a survey of 297 new small enterprises in Romania containing detailed information from the startup date through 2001. We find strong evidence that access to external credit increases the growth of both employment and sales. Taxes appear to constrain growth. The data suggest that entrepreneurial skills have little independent effect on growth, once demand conditions are taken into account, and there is only weak evidence for the effectiveness of technical assistance, and only when it is provided by foreign partners. A wide variety of alternative measures of the business environment (contract enforcement, property rights, and corruption) are tested, but none are found to have any clear association with firm growth.

\footnotetext{
*Corresponding author: 300 S. Westnedge Ave., Kalamazoo, MI 49007 (earle@upjohn.org). We are grateful to Tom Mehen, Raluca Miron, Mircea Trandafir, Irina Vantu, Ruxandra Visan for advice, assistance, and support; and Simon Johnson, Peter Murrell, and Chris Woodruff for comments on earlier drafts. Participants in two CEU Labor Project workshops in Bucharest and a USAID workshop in Washington provided useful comments and suggestions on earlier related work. Loan officers and directors of the CAPA, CHF, and RAEF loan programs and the Center for Urban and Rural Sociology in Bucharest provided indispensable assistance in data collection, which was financially supported by USAID and Phare ACE.. The research for this paper was funded in part through U.S. State Department Grant Number S-LMAQM-00-H-0146, administered by the William Davidson Institute. While grateful to all of these, we bear the responsibility for all findings and conclusions.
} 


\section{INTRODUCTION}

How can policies promote the growth of small startup firms in transition economies? It is hard to overestimate the importance of the development of this de novo private sector in a context where the existing enterprises inherited from central planning face difficult if not insurmountable problems in restructuring and adjusting to the demands of a market economy. ${ }^{1}$ A number of studies have provided evidence that new private firms tend to outperform the old enterprises, and, indeed, many observers have proposed that new private sector growth should be a principal measure of "progress in transition."

The widespread interest in entrepreneurial startups and the policies that affect them, however, has not been matched by anything close to a corresponding research effort. Research on East European economies has paid some attention to factors affecting self-employment decisions, some of which may be classified as entrepreneurial entry, although no such study has yet been undertaken for many of the countries of the region. ${ }^{3}$ But what policy-relevant factors determine whether the embryonic enterprises, once they have been founded, develop into larger firms, creating jobs for workers and producing goods for consumers, or instead languish as tiny "mom-and-pop" operations with relatively few externalities for economic development?

Recent discussions of this question have tended to focus on the possibility that aspects of the business environment - property rights, contract enforcement, efficient regulation - may be important determinants of the small firm growth process, perhaps more important than access to finance. In one of the few empirical studies of firm-level data, Johnson, McMillan, and Woodruff (2000) analyze employment and sales growth from 1994 to 1996 in five countries and find that "[a] lack of bank finance does not seem to prevent private-sector growth" and that "[m] ore inhibiting than inadequate finance are insecure property rights" (p. 1). But these results have been challenged by Pissarides, Singer, and Svejnar's (2003) study of Russia and Bulgaria;

\footnotetext{
${ }^{1}$ Kornai (1990) and Murrell (1992) were perhaps the earliest to emphasize the difficulties of restructuring old enterprises and the crucial importance of new firm growth to economic transition. Johnson and Loveman (1995) examine case studies in Poland, and McMillan and Woodruff (2002) provide a recent overview.

${ }^{2}$ The view that the size of the new private sector is a principal measure of progess in transition can be found, for instance, in EBRD (1999) or World Bank (2002). Studies of the relative performance of new private firms include Earle, Estrin, and Leshchenko (1996), Richter and Schaffer (1996), Bilsen and Konings (1998), Winiecki (2002), and Hellman, Jones, and Kaufmann (2003), although these papers do not focus on obstacles to de novo development. ${ }^{3}$ Earle and Sakova $(1999,2000)$ analyze Bulgaria, Czech Republic, Hungary, Poland, Russia, and Slovakia.
} 
they conclude that "constraints on external financing limit in important ways [the] ability to expand production, [but] do not find insecurity of property rights to be a major constraint" (p. 526). ${ }^{4}$ Still unresolved, the debate over these factors carries important implications for the design of public policies affecting the small business sector. ${ }^{5}$

This paper aims to contribute to understanding the policy-relevant determinants of small firm growth. In some ways, our analysis takes a broader perspective than does the previous research. We have designed a survey instrument that enables us to consider all the major categories of policy-relevant factors that have been discussed in the literature: finance (formal and informal, external and internal), human capital (skills of entrepreneurs, the supply and skills of their workers), technical assistance (business associations, consultancy, and training programs), and the business environment (red tape, contract enforcement, property rights, and other complementary institutions). With respect to each of these, our data contain multiple indicators that attempt - insofar as possible - to provide objective measures of the factor and its precise timing. Where objective measures are difficult to obtain, particularly with some aspects of the business environment, we also use some estimates by managers, and we supplement our findings on the relationships between objectively measured growth and policy-relevant factors with information on managers' evaluations of these relationships. The aim is to consider a wide variety of alternative measures and dimensions of the factors.

We have linked these firm-level survey data to longitudinal information from several sources on employment and sales, which in growth form are the dependent variables in our analysis. This combination of accounting and survey information provides detailed histories of each firm in the sample, with information for each year over the firm's life cycle from startup to the interview date. In this study, therefore, we are able to provide the first analysis (as far as we are aware) of these issues using panel data, with multiple observations on each firm. These data permit us to make use of statistical techniques to isolate the effects of individual factors, taking

\footnotetext{
${ }^{4}$ Related work on investment in small firms in Central and Eastern Europe includes Bratkowski, Grosfeld, and Rostowski (2000) and Johnson, McMillan, and Woodruff (2002).

${ }^{5}$ The issues are relevant not only to transition but also to developed and developing economies. Particularly in developing economies, where factors such as the availability of finance and the quality of the business environment might appear to be important, there has been surprisingly little research on their effects on small firm growth. Liedhom and Mead (1999) survey studies of small firm growth in developing countries, which have focused on sector, region, firm age, and gender of the entrepreneur rather than the effects of policies. Morduch (1999) surveys research on microfinance, which has studied the effects on consumption and income of borrowers and on school attendance of children, but not on job or sales growth.
} 
into account other characteristics of the firm and other factors that may be present, including unobserved heterogeneity, and to specify precisely the timing of the relationship between a change in some factor (for instance, the availability of finance or the receipt of technical assistance) and subsequent firm growth.

Although our data are rich in the longitudinal dimension, in measures of potential obstacles to growth, and in control variables, there are also ways in which our analysis is narrower than some previous studies. We focus on data from only one country, Romania, where we have organized a survey of 297 enterprises that at some point before March 2000 had received a loan from an international microcredit agency. This sampling procedure has the advantage of a very high response rate (90 percent) of owner-managers and accountants to a long questionnaire requesting very detailed and sensitive histories of the firm's finances and information on obstacles to growth, including a number of questions on bribery and corruption. The high response rate was achieved because our research team received the support of the loan agencies in approaching the firms, and we doubt that the information could have been obtained without this support. A drawback of the sampling method is that it limits the inferences that may be drawn from our analysis about the effects of changes in the relevant factors on a different group of firms, the "external validity" problem that may arise in any nonrandom research design. ${ }^{6}$ This suggests appropriate caution should be exercised in drawing policy conclusions concerning, for example, the extension of microcredits to all small firms in Romania or even to a much larger number of firms.

But these considerations do not affect the internal validity of the analysis, involving such questions as the effect of doubling the size or frequency of loans and technical assistance, for example. Our data show substantial variation over time in the factors for each firm in the sample, which we may exploit in a within-firm analysis. Most policy evaluations are in fact restricted to estimating "the effect of treatment on the treated," permitting an extension of the findings only to firms with a common statistical support (Heckman et al., 1998). In such cases, our analysis could be informative about such policy changes as an extension of the loan or technical assistance program to twice as many firms, particularly if the next group of firms on the queue to receive such assistance tend to be similar to the recipients. These policy changes

\footnotetext{
${ }^{6}$ Meyer (1995) contains a discussion of internal and external validity and other research design issues associated with quasi-experimental methods.
} 
are in fact much more realistic options than extending the programs to the entire population of firms. Based on a homogeneity assumption, the analysis would also be informative about the effects of an improvement in entrepreneurial skills, worker education, or the business environment.

Another way in which our analysis differs from previous research is that the firms in our data tend to be drawn from the smaller end of the size distribution. Most of the literature studies the entire "small and medium enterprise (SME)" sector, including in the analysis firms with as many as 250 employees and paying little attention to the smallest category of micro enterprises (those with fewer than 10 employees). ${ }^{7} \quad$ The larger SMEs may be inherited state-owned enterprises or spin-offs from such firms, and thus not genuinely new startups, or they may be extraordinarily successful new firms, but they are unlikely to be typical. Micro firms represent the overwhelming majority of small firms, for example accounting for 92.8 percent of all SMEs in Romania in 1999 (National Agency for Regional Development, 2000). ${ }^{8}$ While our sampling procedure did not restrict size, in fact more than two-thirds of our sample are micro-a set of firms that have successfully started up, but whose further growth is far from assured.

An important problem in analysing the potential determinants of firm growth concerns the identification of causal effects of these determinants. Like previous studies, we take a reduced form approach to causal identification, and we handle the problem of inference in several ways. First, detailed survey data permit the analysis to control for relevant third factors. These variables include not only industry, region, and year effects, but also firm age and size (to control for life cycle growth patterns), dummies for reorganizations in the current year (which may confound the growth measure), and product demand controls such as local population and industry-region growth in sales and employment (which may be correlated both with growth and with the determinants of interest). Second, our focus is on growth rather than level of sales and

\footnotetext{
${ }^{7}$ The standard definition of micro firms is 0-9 employees, small firms 10-49, and medium-sized 50-249. Johnson, McMillan, and Woodruff (2000 and 2002) exclude micro firms and those with employment over 270 (pp. 14-15); the average employment in their sample of Romanian startups is 45.5. Pissarides, Singer, and Svejnar (2003) exclude firms with more than 200 employees and report average employment in their samples at 33.0 in Russia and 27.3 in Bulgaria. The average in our sample is 18.6 employees. For Romanian reports on the overall SME sector, see Romanian Center for Small and Medium Size Enterprises (1998) and National Agency for Regional Development (2000), and see EBRD (1999) for information on several countries.

${ }^{8} \mathrm{~A}$ further problem is that some data sets do not provide enough information on the history of the firm to permit any evaluation of the firm's origins, so that the new private sector is identified with the SME sector, although the latter may include firms that are neither new nor private. World Bank (2002) evaluates the performance of 20 or so different transition economies using this approach applied to official statistics on the firm size distribution.
} 
employment, as firm idiosyncrasies are likely to be important determinants of the latter. Third, a feature of our study that is unique in the literature is the use of data containing annual time series observations over the life of each startup firm. These panel data facilitate a precise specification of timing so that the effect of a factor is measured after the factor has changed, and, equally importantly, they permit the use of fixed firm-specific effects to control for unobservable heterogeneity. Finally, the study has devoted much effort to examining the robustness of the results to changes in the specifications: the definitions of the dependent variable growth measures and of the independent variables-of-interest, the inclusion of alternative sets of control variables, the timing of the relationships, and the controls for unobserved heterogeneity.

Section 2 describes the data construction, basic characteristics, and growth performance of the sampled firms. Section 3 analyzes managerial opinions concerning the growth constraints that their firms face. Section 4 discusses objective measures of four sets of potential growth factors: finance, human capital, technical assistance, and the business environment. The panel data regression methods together with the results using objective measures of both growth rates and policy-relevant factors are presented in Section 5. Section 6 concludes the paper with a summary of results and caveats.

\section{DATA}

This paper studies a data set based on a survey of Romanian firms conducted in MayJune 2001 and on sales and employment information linked to this survey from other sources. The survey included two parts. The first was filled out by an accountant, using standard Romanian definitions of key concepts (particularly to measure such variables as number of employees, sales, profits, reinvested profits, and loans). The second part contained questions directed to the owner-manager in a face-to-face interview (to measure the number of working entrepreneurs, their characteristics and opinions, the receipt of technical assistance, and aspects of the business environment). In this section, we describe the sample, discuss possible selection bias, and provide basic descriptive statistics on the sample characteristics and on our measures of employment and sales growth. Our data on the policy-relevant factors potentially affecting growth are discussed in Section $4 .^{9}$

\footnotetext{
${ }^{9}$ Much more detail about the sample, questionnaire, survey organization, and data processing procedures is available from the authors on request.
} 


\subsection{The Sample}

The sample was designed to cover all firms that had received at least one loan from three international microcredit agencies by March 2000. ${ }^{10}$ The motivation for this sample choice was the extreme sensitivity of much of the information that had to be collected, together with the fact that the research team had the support of the agencies in approaching the firms' owners. ${ }^{11}$ Out of a total of 386 such firms, 297 were interviewed, with a refusal rate of about 10 percent. ${ }^{12}$ The data collection combined a survey of manager-owners, conducted in spring 2001, with annual registry and balance sheet data from the National Commission for Statistics and the Ministry of Finance.

Data from these firms were collected for most variables from the firm's start date through mid-2001, so that the entire past of each firm could be studied. ${ }^{13}$ For the purposes of this analysis, "start date" was defined as either the date of starting operations after founding or of the last major reorganization (split-up, merger, or spin-off of the sample firm). The age of the firm (time since start date) is an important variable to control for in the analysis, and its distribution is shown in Table 1.

Table 2 contains the composition of the sample by region, industry, and employment size. The distribution by region follows the geographic spread of the loan programs, with particular concentration in Banat and the West. Concerning the industry distribution, nearly half the sampled firms operate in wholesale or retail trade, but there is also significant representation in several manufacturing sectors, transportation, and a variety of services. The size distribution reveals that 53 percent fall into the "micro" category, with fewer than 10 employees, and an additional 23 percent have between 10 and 19 employees. Only 9.1 percent of the firms are "medium," according to the standard definition of 50-249 employees. Thus, the sample in this study is heavily tilted towards the smallest size categories of firms, unlike most other studies of

\footnotetext{
${ }^{10}$ The three organizations, all of which received support from the USAID in Romania, are the Romanian-American Enterprise Fund (RAEF-Small Loan Program), the Cooperative Housing Fundation (CHF-Micro Loan Program), and World Vision (CAPA).

${ }^{11}$ Although loan officers supported interviewers in approaching the firms, the former did not participate in the interviews nor did they receive any firm-level information, the confidentiality of which had to be guaranteed when it was collected.

${ }^{12}$ A total of 89 firms could not be interviewed, for the following reasons: 4 had been bought out, 20 had closed, 5 did not have the owner-manager present, 19 could not be found, 9 had had their loan foreclosed and therefore did not cooperate, and 32 refused for other reasons.

${ }^{13}$ Some variables representing characteristics of the business environment are not time-varying, however, limiting the ways in which they can be used in the analysis.
} 
the SME sector.

An important concern that may arise with respect to our sample is that there is some form of "selection bias" in the process determining whether firms receive loans from these loan agencies, and therefore that any estimates of the impact of determinants on growth may be biased. As with any nonexperimental design, we cannot entirely exclude the possibility of selection bias, but there are a number of mitigating factors to bear in mind. First of all, most of our determinants are measured in continuous variables that show considerable variability within and across firms. For example, considering the role of debt finance, we note that there are many firm-year observations when there are no loans, and there is enormous variation in the size of loans in those firm-years where they are present.

Furthermore, as in any policy evaluation based on observational data rather than a randomized trial, our main ambition is limited to the "internal validity" issue of assessing "the effect of treatment on the treated." Thus, again using the example of loans, the relevant counterfactual is that the firms in our sample had not received these loans in these years, or that they had received smaller or larger loans. Our use of firm-fixed effects in the estimating equations uses variation in growth rates within each sampled firm, rather than comparing loan recipients with nonrecipients, again using the loan example. The results from this analysis may be generalized only to firms that are similar to those in our sample, and one should be cautious about extrapolations to firms lacking a common statistical support. ${ }^{14}$

The most relevant policy questions, however, concern marginal changes: it is not whether loans should be extended to the universe of all firms in Romania, but rather whether the loan program should be increased (or reduced), either by increasing the loans that the sample firms receive or by raising the number of firms that receive loans. In the latter case, it is plausible that the next several hundred firms in the queue for such loans would be sufficiently similar in their response, and we believe that our results are informative for this policy question, which is much more realistic than a program of universally available loans.

A particular problem with our sample of loan recipients could arise if firms are given loans based on their expected growth in subsequent years. Although we have been concerned about this possibility, there are several reasons why it seems unlikely to produce bias in our data.

\footnotetext{
${ }^{14}$ Heckman et al. (1998) discuss the importance of the common support in estimating treatment effects in the dummy treatment variable case.
} 
First, as in the case of many microcredit organizations, the loan agencies evaluate loan applications based on the credit history and particularly the previous cash flow of the applicant, and they do not even request a business plan for the future. In nearly all cases, collateral with a value about 120 to 130 percent of the loan value is required. Second, the inclusion of fixed effects in our equations controls for fixed differences in the quality of firms that might be associated with different growth rates and different sizes or probabilities of loan receipt. Third, we include other variables to control for differences in demand conditions. Among these variables are population size of the municipality in which the firm is located and the growth in sales and employment of the industry-county; the latter are highly disaggregated (with over 400 categories). Including the measures of finance, human capital, and technical assistance in the equations may also help attenuate this form of bias, as, for instance, a firm anticipating a profitable investment opportunity may be more likely to apply for a loan, to retain profit, and to seek out some technical assistance; including all these in the equation helps control for demand effects.

Another type of selection bias could result from the fact that our database includes only surviving firms. ${ }^{15}$ If the factors that increase growth also tend to raise the probability of survival, as stands to reason, this suggests that our estimates of the effects will be understated, which is of course a caveat about our results. ${ }^{16}$

\subsection{Measuring Small Firm Growth}

The standard measure of growth used in past studies of small firms is the change in the number of workers since startup, a variable that is relatively easy for respondents to remember and that is uncontaminated by price changes (see, for example, Liedholm and Mead, 1999). Moreover, job creation may be an important social goal, and policies to support small businesses are frequently justified on their supposed employment effects (Birch, 1987). ${ }^{17}$ This study also emphasizes employment growth, but using a modified measure that is arguably more appropriate, and it also studies sales growth as an alternative measure. This section describes the employment and sales growth definitions and analyzes how the measures vary with such

\footnotetext{
${ }^{15}$ As discussed above, 20 firms from the original list of 386 had closed by spring 2001.

${ }^{16}$ Another type of selection bias arises if a maximum size constraint is imposed, a standard practice in studying SMEs, but one we did not follow in our analysis.

${ }^{17}$ According to McMillan and Woodruff (2002), "[t]he creation of jobs has been arguably the most important benefit of the new entrants" in transition countries.
} 
characteristics as firm age, sector, region, and year.

The definition of employment growth in the present study differs in a number of important ways from a simple calculation of the change in the number of workers from the firm's startup to the date of interview. To start with, the definition here includes working owners (entrepreneurs), since job creation for owners may be equally valuable, from a social point of view, as jobs created for others. Workers on external (rather than labor) contracts are also included in the definition, as the purpose here is not to distinguish different types of contractual relations. ${ }^{18}$

A still more important feature of the definition of employment growth analyzed here is that we study annual growth rates, rather than total change since startup. The use of annual rates permits a much more precise assessment of the timing of employment growth effects, rather than cumulating over a long period of time. Our analysis of the panel data to link, for each firm, the timing of employment growth to the changes in factors that may be hypothesized to affect this growth. ${ }^{19}$ The startup year is excluded from the analysis because it is typically a highly volatile period in which firms may not fully operate. ${ }^{20}$

Similar principles are applied in our analysis of sales growth, where we study annual rates of change in real (PPI-deflated) sales. Sales are reported cumulatively by year; thus, during the startup year, they are an unreliable measure of average performance due to the ambiguity of the precise date of startup. We therefore restrict the analysis of sales growth to data only from the first full year of operation. Unfortunately, information on sales in 2001 is not available, and all analyses of sales therefore concern data only through the year 2000 .

Figures 1 and 2 contain graphs of the distributions of annual average growth since the

\footnotetext{
${ }^{18}$ On the other hand, unpaid family helpers are excluded, both because their relationship is more frequently parttime and casual (as well as unpaid), and because they cannot be reliably measured in all years. An incidental benefit of including working owners in the definition is that operating firms then always have strictly positive employment, which avoids the problem of zeros in computing ratios and growth rates. Note that many of the sample firms have multiple working owners (the average is nearly two per firm).

${ }^{19} \mathrm{We}$ also examined cross-sectional differences in employment growth, but in this case the measure is scaled geometrically (in other words, assuming a constant exponential growth rate) with the purpose of creating some comparability between firms of various ages. Results from these cross-sectional regressions are qualitatively similar to those reported here, and they are available from the authors upon request. The studies discussed by Liedholm and Mead (1999) use cross sections, but appear to analyze employment growth from startup without scaling by firm age, while our method measures job creation per unit of time.

${ }^{20}$ Indeed, an anomalous finding reported in Liedholm and Mead's (1999) summary of research on Africa, the tendency for firms with a smaller employment in the startup year to grow more strongly than average subsequently,
} 
first full year of operation after startup for employment and sales, respectively. Overall, growth performance was very strong, with average employment growth about 8 percent and average sales growth about 9 percent. Growth performance varied quite considerably across these firms, however. While most firms grew on average, a significant subset experienced no growth or declined. At the top end, 10 percent of firms experienced employment growth averaging over 30 percent a year, and 10 percent had sales growth over 50 percent. Thus, the sample contains enough variation for the study to be able to relate growth to potential determinants. ${ }^{21}$

Table 3 shows that growth rates vary significantly by year, with a general decline over much of the period. To some extent, the decline may be reflecting the recession of the late 1990s in Romania, and it may also reflect age effects: as the firms in the sample grow older, their growth rates follow a typical life cycle decline. This pattern suggests not only that age and year should be controlled for in the statistical analysis, but also that our search for the growth effects due to factors such as loans or technical assistance faces an uphill battle in the face of the life cycle effect.

\section{MANAGERIAL EVALUATIONS OF GROWTH CONSTRAINTS}

Most studies of factors explaining small firm growth rely on managers' survey responses concerning their perceptions of constraints. The problem with such an approach is that the responses to survey questions are clearly subjective and sometimes self-serving; therefore they cannot be taken as conclusive evidence. Nevertheless, such questions do permit the issues to be phrased directly, which is a particular advantage when it is difficult to design objective measures of factors. As a supplement to the analysis of objective factors and growth measures, opinions of entrepreneur-managers were also collected in this project, and they are reported in this section.

The phrasing of the questions involved listing a total of 14 constraints and asking the respondents to rate the degree to which he/she believed that the factor constrained their own firm's growth. Four sets of factors are analyzed:

- finance: capital constraints, lack of collateral, and level of taxation;

- non-financial inputs: difficulties in hiring appropriate employees and in finding adequate premises and supplies;

might be attributable to the fact that the smaller firms had not really started up in that first year but then caught up in the year following. 
- malfunctioning of the business environment: poor contract enforcement, administrative burden of taxation, bureaucratic interference, police protection and private protection payments, and unfair competition; and

- macroeconomic climate: inflation and low demand for goods and services provided by the firm.

The assessment of these factors is measured on a scale from 1 to 5 , where 1 indicates not binding at all and 5 indicates extremely binding. For many purposes, little information is lost by grouping scores 1-3 together as relatively non-constraining and scores 4-5 as very constraining, and the results for the percentage of firms reporting scores 4-5 are presented in Table 4. Results are provided for firms by category of growth rate (below and above the median) and by category of employment size ("micro" = 0-9, "small" = 10-49, and "medium" = 50-249). In addition, respondents ranked the top five "most constraining" factors, and the results are shown in Figure 3.

\section{Financial Constraints}

Consistent with many studies of managerial opinions in small businesses, managers in the firms we survey rank financial factors as substantial constraints on growth. ${ }^{22}$ As shown in Table 4, about 78 percent of firms considered lack of capital as a very constraining factor, and the percentage was higher in slow-growing firms and those in the smaller size categories. Lack of collateral was taken as a serious barrier to accessing credit by 42 percent, although in this case faster growing firms were more likely to cite it as a constraint, while there is no clear relationship with size. $^{23}$ The high level of taxation, which may reduce the possibility of internal finance as an alternative to costly external sources, was considered an important constraint by nearly all firms (91.1 percent), with comparatively little variation by growth rate or size. ${ }^{24}$ As shown in Figure 3 , more than half of the firms reported either lack of capital or the level of taxation as the "most constraining" factor of all.

\footnotetext{
${ }^{21}$ Growth rates by region, industry, year, and age also vary, and we control for them in the analysis.

${ }^{22}$ See, for instance, Pissarides, Singer, and Svejnar (2000) on Bulgaria and Russia, and Barlett and Bukvic (2001) on Slovenia. EBRD (1999) uses a four-point scale, with four implying the highest level of constraint, and reports an average score of 3.11 for financing for startups in 1997-99 across 22 transition economies.

${ }^{23}$ The same percent was obtained in a study carried out by the Romanian Center for Small and Medium Enterprises (1998) in 1996, suggesting there has been little change in collateral demands of the main credit providers.
} 


\section{Labor and Material Inputs}

It is sometimes claimed that well-functioning markets for labor and other production inputs have been slow to develop in the transition economies. Educational systems designed to serve the pursuit of rapid industrialization may be poorly adapted to producing skills appropriate to a market economy, and soft budget constraints may keep resources bottled up in unproductive sectors of the economy. These problems could be particularly acute for small firms and new entrants that would like to expand. In the current study, about one-third of entrepreneurmanagers mentioned hiring as a severe constraint, the problem reportedly greater for slowgrowing firms and for micro and small firms. The availability of non-labor inputs, such as buildings and land, appears to be even less serious, as 18 percent of firms reported difficulties in finding and renting adequate premises (buildings), and about 11 percent were concerned about the reliability of supplies. ${ }^{25}$ These factors were seldom mentioned on the list of worst constraints.

\section{Business Environment}

In order to assess the business environment, respondents were asked to report the degree of constraint associated with a variety of factors concerning contract enforcement, administrative burden of taxation, bureaucratic interference, police protection and private protection payments, and unfair competition. Some recent studies have argued that these factors are particularly important barriers to small firm development. ${ }^{26}$

The survey results, again shown in Table 4, indicate that only 17.7 percent of entrepreneurs consider that at least one type of contract enforcement (with either customers or suppliers) is a very binding or serious constraint. Moreover, protection payments to the police and private parties (mafias), which threaten property rights, are evaluated as serious problems by only trivial numbers of firms. Constraints associated with bureaucratic interference are

\footnotetext{
${ }^{24}$ The survey used for the EBRD (1999) report finds an average score on "taxes and regulation" of 3.26 for all countries and 3.55 for Romania, but unfortunately does not distinguish tax level, administrative burden of taxation, and other regulatory burdens.

${ }^{25}$ The problem appears to be greater for SMEs elsewhere in the region. Pissarides, Singer, and Svejnar (2000), for example, report that 52 percent of the Russian and 55 percent of the Bulgarian managers in their sample considered that "getting land, office space and buildings" was a very important constraint; the data pertain to 1995, still very early in transition, however, compared to the present study's information on Romania in 2001. EBRD (1999) returns fairly low values for "infrastructure": an average of 2.07 for all countries, and 2.51 for Romania.

${ }^{26}$ See EBRD (1999) and Johnson, McMillan, and Woodruff $(2000,2002)$.
} 
somewhat higher, with about one-third of firms reporting serious problems, a fraction that is higher in slower growing and smaller enterprises; about 5 percent of firms reported this problem as the most constraining they faced. Nevertheless, by these conventional measures, the business environment appears to be less constraining than recent claims suggest.

More important in these managerial opinions is the allegation that some competitors receive unfair advantages on the market, with about 47 percent of firms considering unfair competition a binding factor. ${ }^{27}$ Whether competition is evaluated as "unfair" could certainly involve some subjectivity, but in the Romanian context it may reflect the presence of subsidies or regulations favoring larger, state-owned firms (particularly regii autonome) or jealousy over special preferences granted to foreign investors, which have been quite controversial in the country. Also, Romanian mass media often report cases of unfair benefits received by firms with strong political connections. About 6 percent of firms report this factor as the most constraining.

Still more substantial is the view that the administrative burden of taxation is an important constraint, with 90 percent of managers so reporting. This variable is unusual in studies of small firm growth, as the level and administrative burden of taxation are rarely distinguished. ${ }^{28}$ But it does represent an aspect of the environment for business that may be influenced by government. In any case, despite the fact that most managers take a dim view of the complexities of the tax code, few cite it as one of the most constraining factors, implying that it is relatively less important than some of the others.

\section{Macroeconomic Climate}

Inflation was viewed by most firms as a severe constraint, and about 30 percent cited it as the single most constraining factor, as shown in Figure 3. Low demand for the firm's products was cited as a constraint by 37 percent, but it was one of the most important factors for very few firms. These results suggest that, to small firms, macroeconomic stability is viewed as more important than demand growth; apparently most of these firms believe they have a market, but they require a stable environment to be able to make pricing and other business decisions.

\footnotetext{
27 The Romanian Center for Small and Medium Enterprises (1998) report a similar response in their study using 1996 data. Unfair competition was reported to be the second most serious constraint on sales.

${ }^{28}$ Administrative burden is also not the typical measure of the business environment employed by studies such as EBRD (1999) and Johnson, McMillan, and Woodruff (2000, 2002). As noted above, EBRD (1999) combines "taxes and regulations" into a single category.
} 


\section{OBJECTIVE MEASURES OF POTENTIAL FACTORS AFFECTING GROWTH}

This section presents our measures of factors that may promote or constrain the growth of the sample firms. We refer to these measures as "objective," and for the most part the variables do refer to quantities that may be independently verified and that are defined according to generally accepted and interpersonally comparable metrics. Some of the variables, however, result from questions in which manager-owners were asked to estimate some factual condition or circumstance. Such measures are particularly important in the business environment section of the survey, when respondents were asked about various aspects of government regulation and interference, contract enforcement, property rights, and corruption. With respect to these estimated variables, however, our method remains the same - to investigate their effects on firm growth in a multivariate panel framework - and thus the empirical strategy differs from the standard analysis of managerial opinions concerning growth constraints presented in the previous section.

Our classification of potential growth factors emphasizes policy-relevant variables and draws upon previous research on one or another aspect of these issues. The four sets of factors, in our classification, are as follows:

- finance: retained earnings, conventional bank lending, informal credit markets, "fiscal facilities" offered by the state, and international aid programs;

- human capital: education, experience, and other characteristics of both entrepreneurs and their workforces, including training and constraints on hiring;

- technical assistance: membership in a business association and training and consultancy programs from a variety of sources; and

- business environment: red tape, contract enforcement, property rights, and corruption.

Each of these factors has been the subject of considerable discussion, but no prior study has considered all of them simultaneously and attempted to evaluate their relative importance on firm growth performance. In this section, we present our measures for each set of factors in turn.

\subsection{Finance}

We approach the controversial question of potential financial constraints on firm growth by an array of measures, including the size, number, and source of loans, the rate and amount of reinvested profit, and the extent of access to "fiscal facilities" lowering taxes. Starting with loans, the Romanian survey sample includes only firms that have received a loan from a USAID- 
supported program; thus all these firms have received at least one loan. Many of them had received loans from other sources, and the USAID-supported loans account for only half the total loans reported by the sample firms since their founding. We include all types of loans in the analysis, without distinguishing the origin.

It is important to note that not every firm had an outstanding loan every year, however. Indeed, in most years of their operations, the sample firms had no outstanding loans whatsoever. Moreover, some firms received much larger loans than others. The amount of loans, therefore, varies considerably both across firms, and over time for each firm.

Tables 5 and 6 provide information on the incidence and size of outstanding loans, measured as a ratio to employment and sales. ${ }^{29}$ Only from 1999 did the percentage rise over 50, and it peaked at 75 percent in 2000, falling to 68 percent in 2001 . The mean outstanding loan per employee is generally about $\$ 3000$, for firms that have them, and when the Romanian lei value of sales is converted at current exchange rates, the mean loan amount is about 70 percent of sales; for Romanian firms, these are substantial loans. ${ }^{30}$

An alternative to external finance is reinvesting profits. Table 7 shows the variation in the percentage of profit that firms report reinvesting. The low reinvestment rates in some firmyears may be accounted for by the lumpiness of investment projects whose financing requires multiyear savings from profits. In addition, in many firms it may be the case that entrepreneurs' sole source of income is profit (particularly in unincorporated firms where owners are not also employees). The fraction of firms reinvesting is higher earlier in the period, but the average rate among those reinvesting is fairly constant at about 80 percent.

The relevant notion of profits for reinvestment purposes is net or after-tax profits; thus the extent to which firms have profits to reinvest is influenced by their tax rates. A particularly interesting policy in this respect has been the granting of so-called "fiscal facilities," tax

\footnotetext{
${ }^{29}$ The size of the loan is measured as the sum of the amounts in the second half of the previous year and the first half of the current year. The amounts are determined by the extent to which the loan expands financial possibilities in that year, defined as the full amount of the loan in the first half year of disbursement and declining linearly over the term of the loan thereafter. These calculations assume that the loan is repaid in equal installments continually over the term, which is the most common practice (usually, monthly). We also estimated the equations with a variety of alternative specifications, for instance the magnitude of loans in year $t-1$, with very similar results to those reported here.

${ }^{30}$ Concerning the sources of finance, informal loans from family, friends, and loan sharks account for a rather small percentage of the total (about 3.5 percent), while formal loans from banks and international organizations account for 95 percent. Interfirm credit also plays only a small role for our sample firms, in contrast to McMillan and Woodruff's (1999) analysis of firms in Vietnam.
} 
reductions given for a variety of reasons and under a variety of programs (60 percent reduce the profit tax and another 15 percent reduce import or export taxes). Few of them are tied directly to employment increases. Unfortunately, the value of these benefits is difficult to quantify, but Table 7 shows the percentage of firms reporting receiving them and their number by year. About 90 percent of the sample did not receive any facility in any given year, but those who did had extra financial resources that they could use to grow.

\subsection{Human Capital}

Although it is frequently claimed that the transition economies of Eastern Europe started the process with relatively strong human resources due to well-developed educational systems, it is less clear that the skills of the population were well-geared toward entrepreneurial endeavors or toward responding to the demands of the market rather than central planners and factory bosses. Table 8 shows some characteristics of entrepreneurs in our data. These are computed by taking the share-weighted average across owners for each year and for each firm, averaging these across years for each firm, and then averaging across firms. The figures thus give the average percentage ownership by each characteristic. ${ }^{31}$

The table shows that women own an average of about 30 percent, while only 0.7 percent is accounted for by foreigners. ${ }^{32}$ Reflecting the depth of the restructuring process in the Romanian economy and the decline in the value of skills obtained under central planning, most entrepreneurs in our sample are new to the industry in which their firms operate: 59 percent worked outside the industry prior to starting up the firm. Entrepreneurs tend to be well educated, with 49 percent having completed some form of university education, and an additional 32 percent having completed academic secondary schools. Most entrepreneurs are in their 30s and early 40s, and an unusually low fraction is over 50 years old. ${ }^{33}$

\footnotetext{
${ }^{31}$ If each firm had a single, unchanging entrepreneur, this would correspond to the percentage of entrepreneurs, but with multiple entrepreneur-partners holding differential ownership stakes, it is important to take into account these weights in estimating the relative importance of each characteristic. The characteristics are unchanging, so the fixed effects regressions, of course, rely on changes over time in ownership. An entrepreneur may sell the business to another or take on an additional partner, for example.

${ }^{32}$ Although gender and nationality may be less obviously policy-relevant than education, in fact many microcredit programs in developing countries have been targeted to women, while foreign participation in the small business sector is a function of policies towards immigration and capital flows, among others.

${ }^{33}$ The study also investigated a variety of other characteristics of entrepreneurs, including their family backgrounds and their experience prior to 1990 (including political background), but these variables were unassociated with measured firm performance in this data set.
} 
The survey also contains information on workers' characteristics, including their educational attainment. By contrast with their employers, few employees had university education: 12.6 percent, about the national average. About 33 percent of workers had not finished high school.

A final human capital measure is a proxy variable for the difficulty of hiring, analogously to the managerial opinion variable on this topic in Section 3. Our measure is the respondent's estimate of the costs of hiring an additional worker, including all the time spent advertising, interviewing, selecting, and training a new employee. The range of this variable is from zero to 480 hours, with a mean of 45.9 and median of 24.0. The survey also asked about initial training costs, measured in time; the mean was 54 days for a newly hired unexperienced worker, and 22 days for those with some experience. In some specifications, we summed the hiring and training times to obtain a measure of the total cost.

\subsection{Technical Assistance}

Much effort and many financial resources have been expended on the design of technical assistance programs for small firms in transition economies, but rather little evidence is available on how well these programs have functioned. Relatively few firms in our data report actually having received technical assistance: about 30 percent overall, 10 percent receiving only training, 9 percent receiving only consulting, and 10 percent receiving both.

Although most firms do not receive technical assistance, those that do tend to receive multiple services. The types of services received, source of financing, and service providers are shown in Table 9. Most common are consulting in marketing and training of entrepreneurs and workers. About half the services were paid for by the firm itself, while USAID accounts for only 13.5 percent. Both domestic and foreign/international providers are represented in our data.

Respondents were also asked to rate the usefulness of each instance of technical assistance on a three-point scale ("not useful at all," "somewhat useful," and "very useful"). Despite the low incidence of technical assistance, the recipients rate what they have received very highly, 75.0 percent of services being rated "very useful" and an additional 21.5 percent "somewhat useful." These subjective ratings, while informative, cannot be equated with evidence of a positive effect of receipt of technical assistance services on the firm's growth rate. Such evidence requires multivariate analysis of factors explaining growth, including technical assistance. 
Donors have actively promoted business associations as an important way to promote SME development. Only 28.5 percent of the firms in the sample are members, however. Members report wanting to be a part of business associations for several purposes, the most common being consulting services, locating customers and suppliers, and training. Many of the other firms report not being members because the services are not useful or membership is not worth the cost.

\subsection{Business Environment}

The final set of factors concerns the environment within which firms operate: costs of registration and problems with bureaucracy, use of the courts and other means to handle disputes, predatory behavior from police and private parties, and the extent of under-reporting of financial indicators. ${ }^{34}$ Obtaining accurate indicators for these factors is difficult, and the survey attempted a wide variety of alternative measures.

The costs of registration are frequently used as a measure of bureaucratic interference into small firm operation. In the Romanian case, the approval of three different agencies was necessary during most of the period we are studying: the Ministry of Finance, the Ministry of Labor and Social Protection, and the Registry of Trade and Commerce. It is frequently maintained that bribes are either necessary or useful for expediting the registration process, and our questionnaire asked respondents to estimate the distribution of the total monetary cost among official payments, unofficial payments (bribes), and consulting fees (which might also be partly bribes). ${ }^{35}$ Official payments account for 90 percent, consulting fees for 7 percent, and bribes only about 3 percent, according to the responses of the owner-managers we interviewed.

The survey also collected information on the number of permits required for the firm to operate in the first year after founding and the number of government inspections that took place that year. While most firms needed relatively few permits and received a moderate number of inspections (in both cases defined as less than ten), some firms experienced more bureaucratic

\footnotetext{
${ }^{34}$ IRIS (2000) contains a detailed discussion of legal procedures, regulation, and taxation of small businesses in Romania.

${ }^{35}$ Anecdotal evidence suggests that bribes are frequently paid indirectly, through a third party; for instance, a lawyer or other agent may be hired to carry out the registration, and part of the "fee" paid to this agent may end up in the hands of the bureaucrat. Most surveys of corruption fail to measure this channel.
} 
hassles. $^{36}$

Most firms have disputes with customers or suppliers at some time or other in their history, but an interesting question is how the disputes are handled. Survey respondents were asked to specify the dispute-resolution methods they had used in the past and the single method they would most likely use in the future. The results show that going to court is common (58.6 percent of firms report having done so, and 37.7 percent say this would also be the most likely future method), but still more common is resolving never to deal with the party again.

To elicit truthful responses on protection payments, firms were asked to specify the incidence in their sector. Only about 7 percent of firms say "rather yes" to the statement that it is sometimes necessary for firms in the sector to make such payments to either private parties or the police.

Respondents were also asked whether they were willing to pay for a clean business environment. Of 282 respondents, 77 percent claimed they were willing to pay, and the amounts they reported to be willing to pay were not inconsequential (5-10 percent of sales).

A final indicator is truthful reporting. If a firm has little to fear from predatory government bureaucrats or private mafias, it is more likely to truthfully report financial indicators. Firms were asked to estimate the extent of under-reporting by "other firms in the same industry and region." The results show that an average of 24 percent of employment, 32 percent of wages, 28 percent of profits, and 25 percent of sales are said to go unreported. According to these measures, the hidden economy is quite substantial in Romania. ${ }^{37}$

\section{ESTIMATION FRAMEWORK AND RESULTS}

This section reports regression results relating employment and sales growth to the four types of factors, while controlling for other relevant variables: firm age, past and current reorganizations (two dummies, one for mergers and acquisitions, and the other for split-ups and spin-offs), size category, local growth of the industry (2-digit industry in each county), size of

\footnotetext{
${ }^{36}$ IRIS (2000) claims that it was not only the number of required permits that bothered firms, but also the cost of preparing the necessary documentation to get permits; the median amount of time preparing documentation for the Trade Registry was seven days, for example. In the current survey, the median respondent reported a total of 30 days of work for filling out forms and dealing with the Trade Registry, the fiscal authorities, and the Labor Chamber in order to be able to operate, but this variable was unassociated with subsequent firm growth.

37 A recent paper estimating the size of the shadow economy labor force as a percentage of the working age population in 22 transition countries reports a figure of 24.3 percent in Romania, just above the Central and East European average of 23.3 percent (Schneider, 2002).
} 
the city where the firm is located, industry, region, and year dummies. Life-cycle considerations and previous studies of firm dynamics suggest that growth rates decline with firm age and size. By definition, mergers and acquisitions should be associated with growth, and split-ups and spinoffs with contraction. Firms in larger cities may have more growth opportunities. Local growth of the firm's industry further controls for demand conditions. Industry and regional dummies provide still more controls for demand and other factors not otherwise included, and year dummies control for macroeconomic shocks. The regressions are based on a 1994-2001 panel. The equations we estimate are all variants on the following basic form:

$$
\begin{aligned}
y_{i t}=\beta_{1} \text { Finance }_{i t-1}+\beta_{2} \text { HumanCapital }_{i t-1}+\beta_{3} \text { TechnicalAssistance }_{i t-1}+\beta_{4} \text { BusinessEnvironment }_{i t-1} \\
+\gamma_{1} \text { Age }_{i t}+\gamma_{2} \text { Reorganized }_{i}+\gamma_{3} \text { FirmSize }_{i t-1}+\gamma_{4} \text { LocalGrowth }_{i t} \\
+\gamma_{5} \text { CitySize }_{i}+\gamma_{6} \text { Industry }_{i}+\gamma_{7} \text { Region }_{i}+\alpha_{t}+\alpha_{i}+\varepsilon_{i t},
\end{aligned}
$$

where the $\beta$ are the parameters of interest corresponding to policy-relevant factors, and the $\gamma$ reflect the impact of controls. In alternative versions of this equation, $y_{i t}$ represents employment and sales growth $-\ln \left(E_{i t} / E_{i t-1}\right)$ and $\ln \left(S_{i t} / S_{i t-1}\right)$ —and different specifications of the policy-relevant factors are employed. Summary statistics for these variables, which are based on those discussed in Section 4, are provided in Table 10, and precise definitions may be found in the data appendix. Controls that do not vary over time (subscripted with only an $i$ ) drop out of the equation when the firm fixed effects $\alpha_{i}$ are included, as does firm age, when both $\alpha_{t}$ and $\alpha_{i}$ are included. In most specifications we include the $\alpha_{i}$ to control for unobserved firm heterogeneity, but as some business environment measures are contemporaneous or refer to the firm's startup period, we also estimated every equation by OLS. An additional advantage of OLS is greater robustness in the presence of classical measurement error.

We report the results from estimating this equation first with a base specification that includes some measures of finance, human capital, and technical assistance. These results, for both pooled OLS and firm fixed effects (FE) specifications are shown in Table 11. Tables 12, 13, and 14 then show results from alternative specifications of the financial, technical assistance, and business environment factors, respectively, while retaining the same controls and the variables associated with the other factors from Table 11. The results shown are only a small fraction of all we estimated, permitting variation in the choice of variables, timing, controls, and use of firm fixed effects.

The results in Table 11 imply a positive impact of the relaxation of financial constraints 
through loans in one year on employment and sales growth in the next. The impact on employment growth is statistically significant in both the OLS and FE specifications, while for sales it attains statistical significance at conventional levels only in FE. The magnitudes suggest that doubling the size of loans would raise the employment growth rate by between 3 and 7 percentage points, the latter implying a doubling of the annual average growth rate displayed by the firms over this period (which was 7 percent, as shown in Table 3). These results are quite robust to alternative specifications of the timing of the loan variable, for which we exploited the availability of detailed information on the timing of all the firm's loans. In particular, we examined the effect of average loans over the years $t-1$ and $t$ and those in the second half of year $t-1$ and the first half of year $t^{38}$ We also estimated the equation with the loan variable in linear rather than logarithmic form, and in absolute form (not scaled by employment or sales). The results from all these robustness checks were qualitatively very similar to those presented here.

"Fiscal facilities" provided by the state consistently and substantially raise employment growth, as also shown in Table 11. In the OLS specification, an additional fiscal facility in one year is estimated to increase employment growth by 4 percentage points, while in the FE the effect is estimated to be 8 percentage points. When considered relative to the average baseline employment growth of 7 percent, these results suggest that the high statutory tax rates represent a significant financial constraint on small firm employment expansion. This is consistent with the evaluations of about one quarter of the entrepreneur-respondents in our sample that the level of taxation is the most constraining factor for the development of their firm. The estimated effect of these subsidies on sales, however, is smaller in magnitude in the FE specification, and it is statistically insignificant for both OLS and FE.

Turning to alternative specifications of finance, in Table 12, the proportion of reinvested profit is estimated to have a strong positive effect on both employment and sales. The estimates for trade credit, while usually positive, are more sensitive to inclusion of specification and are not usually statistically significant (only in the OLS specification of equation 3 for employment growth in Table 12). So far, the results support the proposition that financial constraints are highly significant for the sample firms, as an increase in credits and in reinvested profit raise

\footnotetext{
${ }^{38}$ Consistent with our definition of the one year lagged variable, these measures of outstanding loans are calculated assuming a linear repayment schedule, thus a linear rate of decline the degree to which the financial constraint is relaxed.
} 
both employment and sales growth, while tax relief through fiscal facilities is estimated to raise employment.

The effects of the human capital variables on employment and sales growth are weaker in general than those for financial constraints. Few variables are statistically significant, particularly in the fixed-effects specifications. The negative, slightly convex relationship between both growth measures and entreprenuerial age, found in the OLS specifications, disappears once firm fixed effects are added. ${ }^{39}$ Note that the demand proxies in the equations, such as the growth of sales and employment in the county-industry, control for the possibility that an anticipated increase in demand may lead to more skilled entrepreneurs taking over the business. Without the demand controls, in fact, the result for entrepreneurial education is much stronger. The results for worker education are also small and imprecisely estimated.

Technical assistance is associated with faster employment and sales growth in the OLS equation, but the estimated coefficient becomes statistically insignificant when firm fixed effects are added. As shown in Table 13, there is some evidence of a positive effect of technical assistance only when it comes from a foreign partner or international organization, and only is the impact of the latter marginally statistically significant (at the 10 percent level) when firm fixed effects are added - and only in the employment growth regression. None of the variables shows a positive effect on sales growth once firm fixed effects are added. The combination of sometimes positive OLS and insignificant fixed-effects results suggest that the firms with better growth opportunities received technical assistance, but that the technical assistance itself had no impact.

Finally, regressions were run using many different measures of the business environment, including measures of corruption, competition, permits, inspections, and problems with contract enforcement and property rights. ${ }^{40}$ Among hundreds of alternative specifications investigated, no evidence was found that these variables constrain growth. ${ }^{41}$ To some extent, the comparative

\footnotetext{
${ }^{39}$ As noted above, the fixed-effects specifications rely on changes in entrepreneurial characteristics due to change of ownership, bringing in new partners to the business, changes in shares of the partners, etc. It is possible that there is simply not enough within-firm variation in the characteristics to permit reliable fixed-effects estimation.

${ }^{40}$ The survey provides about 30 alternative measures of the business environment, not counting measures of competition. The regressions attempted various combinations of these, using cross-section as well as panel specifications, and alternative sets of controls (including very parsimonious equations with few or no controls).

${ }^{41}$ Johnson, McMillan, and Woodruff (2000) similarly find little evidence of a relationship between property rights enforcement and growth in Poland, Romania, and Slovakia, which they report to have significantly better property rights enforcement than Russia or Ukraine. One interpretation of the evidence is that below a certain level of
} 
lack of strong results in this area may simply reflect the difficulty of finding reliable measures of the relevant concepts, particularly time-varying measures for each firm, but the results at least provide a caveat for policies and programs that would reallocate resources towards business environment issues at the expense of providing finance in Romania.

\section{CONCLUSIONS}

Although the importance of small startup companies for economic growth and innovation is widely recognized in all types of economies - developed, developing, and transitional - there has been relatively little research into the policy-relevant factors that stimulate their growth. Studies of managerial opinions concerning the obstacles faced by their firms are useful and suggestive, but we believe that there is a need for careful quantitative studies using panel data to analyze the statistical relationship between firm growth and objective measures of factors related to policies. In this study, we have attempted to begin to fill this gap, using a remarkable data set with detailed information over the entire lifespans of firms. Here, we summarize the conclusions from our analysis of these data, and we also discuss caveats that are important in interpreting our work and that suggest how future research may proceed.

The results provide strong evidence that loans are an important factor in stimulating the growth of small startup firms in Romania. The availability of internal finance also promotes growth, but trade credit appears to be relatively unimportant. This finding, which is highly robust to alternative specifications and methods of estimation, runs counter to the claims of some recent studies that finance is not an important constraint for small firm growth in Eastern Europe. Among the financial determinants of growth, "fiscal facilities" provided by the state consistently and substantially raise employment growth, suggesting that statutory tax rates represent a significant financial constraint on small firm expansion. ${ }^{42}$ These results are consistent with managerial evaluations of finance and taxes as substantial constraints on growth.

Other factors tend to be much weaker and more sensitive to specification. Concerning human capital, there appears to be little relationship between entrepreneurial characteristics and growth, once demand factors have been included in the equations. Worker characteristics and measures of hiring costs are also unassociated with growth, consistent with the evaluations of

property rights protection, the policy emphasis should be on improving protection, but once protection has reached a certain level, improving access to finance may have a bigger payoff for growth. 
managers that hiring difficulties are not important constraints. There is little evidence of any association of technical assistance with growth.

A final set of policy-relevant variables concerns contract enforcement, property rights, and other aspects of the business environment. Although transition economies have stimulated fascinating discussions of these issues, the analysis in this paper reveals that the relationship between measures of the business environment and firm performance is weaker than it is for the other factors. Among many variables investigated - including measures of corruption, permits, inspections, and problems with contract enforcement and property rights-little or no evidence was found that they constrain growth. Again, these results are consistent with the low weight placed on such constraints in managerial evaluations.

These policy conclusions are of course subject to a number of caveats. First of all, the specific conclusions are limited to the sample of firms analyzed in this study. All of these firms are unusual, at least in the sense that they received a USAID-sponsored loan, and thus their average quality may reasonably be supposed to be higher than the average in the entire universe of small Romanian enterprises. Although our use of fixed effects controls for quality differences among the sample firms, extrapolating the study's exact findings to a broader category of firms requires an assumption that the factors that influence growth are similar in both cases.

On the other hand, our assessment, as in any policy analysis, is limited to "the effect of treatment on the treated." Using the example of loans, the relevant counter-factuals are that the firms in our sample had not received these loans in these years, or that they had received smaller or larger loans. The results may be generalized only to firms that are similar to our sample firms. The relevant policy question, however, is not whether loans should be extended to the universe of all firms in Romania, but rather whether the loan program should, for example, be doubled in size, either by doubling the loans that the sample firms receive or by doubling the number of firms that receive loans. If small firms in Romania are indeed capital-constrained, as our evidence strongly suggests, then we doubt that the next 300 or so firms in the queue for finance would differ materially from the 300 who did receive the USAID loan. Thus, for such policy questions, our results may provide some guidance. ${ }^{43}$

\footnotetext{
${ }^{42}$ The Romanian government has recently removed many of these facilities.

${ }^{43}$ Moreover, a possible implication of a systematic quality difference between our sample and the population of Romanian firms could be, assuming that firms of lesser quality tend to be more credit-constrained, that our estimated
} 
Concerning sample size, the number of firms and years in this study is larger than in most other studies of firm performance in transition economies, but it is still small enough to suggest caution in interpreting the results. The use of time series information on each firm and the focus on micro enterprises - which are advantages of this study relative to other research is this areamitigate the problem to some extent, but not entirely. For instance, the estimates of the number of jobs created by loans fluctuate depending on the precise measures and statistical methods employed in the analysis. The positive association of higher employment growth and receipt of loans is strongly supported by the data, but the precise point estimates of the magnitude of job creation should be treated with caution.

The strength of our conclusions is also limited by measurement difficulties. With respect to the business environment, for example, the extent to which contracts are enforced and the degree to which property rights are respected are variables that are difficult to measure. Although we collected information on a wide variety of alternative measures and explored many different ways of estimating their effects, the finding of little relationship between these variables and firm growth may simply reflect the difficulty of measurement.

Inferences concerning the association of firm growth with the potential factors may also be limited by lack of variation in the sample. To take the business environment variables again as an example, it is possible that their variation within Romania is insufficient to be related to differences in growth rates. Perhaps all firms are equally constrained by these factors. In fact, however, the survey data do show fairly substantial variation in both the business environment measures and in growth rates.

The final caveat concerns the limits of statistical methods to yield causal conclusions. While the study has made every effort to isolate the effects of individual factors and to estimate their magnitudes, in particular through the use of panel data techniques and careful specification of the timing of the relationships, the possibility of reverse causality remains. For instance, it is possible that firms with superior growth prospects tend to receive bigger loans; in this case, the loan effect would result from careful selection by loan officers, rather than through relaxation of the financing constraint (and monitoring of the firm's behavior). On the other hand, the credit

positive effect of loans on growth is actually understated relative to the population average effect. For the business environment, however, the possible bias may go in the other direction if successful firms are more subject to bureaucratic and other forms of predation, implying that our estimated negligible effect is if anything overstated. 
agencies evaluating the loan applications in our data do so based on the firm's collateral, credit history, and previous cash flow, rather than the particular project for which the loan would be used. Moreover, the inclusion of firm fixed effects and demand indicators help control for this form of selection bias. Our identification of growth spurts in the period immediately following the receipt of a loan is strong evidence that the loan is the driving force in increasing growth, rather than vice versa, but we cannot entirely exclude the possibility that some dynamic selection mechanism also plays an important role. 


\section{APPENDIX: VARIABLE DEFINITIONS}

\section{GROWTH MEASURES}

Employment Growth is the log of the ratio of current employment to employment in the previous year, where employment level is defined as the sum of regular workers, contract workers, and working entrepreneurs.

Sales Growth is the log of the ratio of sales in the current year to sales in previous year, where sales level in ROL is converted to 2000 prices using implicit price deflators at the 2-digit CAEN aggregation level. CAEN is the Romanian National Classification for Economic Activities (NACE).

\section{FINANCE}

Loans is the natural logarithm of the average amount of loans outstanding in year $t-1$ plus one, scaled by the average of employment in year $t-1$ and $t-2$ (in employment growth regressions) or by average sales in year $t-1$ and $t-2$ (in sales growth regressions). Outstanding loans include any new loans received during the period plus a fraction of not yet matured loans received in previous periods, where the average amount outstanding is computed assuming constant proportionate repayment over the life of the loan. The amount of loans over other time periods (for instance, lagged six months) are computed similarly.

Reinvested Profit is the proportion of net profit reinvested in year $t-1$.

Fiscal Facilities is the number of fiscal facilities received in year $t-1$.

Proportion of Materials Bought with Trade Credit is the average proportion of materials bought with trade credit in year $t-1$.

\section{HUMAN CAPITAL}

Entrepreneur Experience in Other Industry is the average proportion of ownership in year $t-1$ held by individuals who worked in another industry prior to owning shares in the firm.

Entrepreneur Age is the average age of individual owners in year $t$-1, weighted by their proportional ownership. 
Entrepreneurs with High School is the average proportion of ownership in year $t-1$ held by individuals whose highest educational attainment is a high school education.

Entrepreneurs with University is the average proportion of ownership in year $t$-1 held by individuals whose highest educational attainment is a university education.

Foreign is the average proportion of ownership in year $t-1$ held by foreign individuals.

Female Entrepreneurs is the average proportion of ownership in year $t$ - 1 held by females.

Workers with High School is the proportion of workers on regular contracts in mid-2001 whose highest educational attainment is a high school education.

Workers with University is the proportion of workers on regular contracts in mid-2001 whose highest educational attainment is either a short- or long-term university education.

\section{TECHNICAL ASSISTANCE}

Number of Technical Assistance Services is the number of services in year $t-1$.

Number of Training Services is the number of training services in year $t-1$.

Training for Workers/Managers is the number of training services for workers/managers in year $t-1$.

Number of TA Paid by Firm is the number of services paid by the firm in year $t-1$.

Number of TA from Government is the number of services provided by government in year $t$ 1.

Number of TA from NGOs is the number of services provided by NGOs in year $t-1$.

Number of TA from Foreign Partners is the number of services provided by foreign partners in year $t-1$.

Number of TA from International Organizations is the number of services provided by international organizations in year $t-1$.

\section{BUSINESS ENVIRONMENT}

Proportion of Permits Not Obtained is the proportion of permits that the firm did not have, but should have had by law in year $t-1$. 
Number of Permits in First Year of Operation is a dummy equal 1 if the number of permits needed during the first year of operation was greater than 9 .

Number of Inspections in First Year of Operation is a dummy equal 1 if the number of inspections needed during the first year of operation was greater than 9 .

Disputes per Year is the number of contract disputes that could not be resolved through direct negotiations that the firm has ever had, divided by the number of years in operation.

Dummy for Protection Payments to Private Parties is a dummy equal 1 for firms in the same industry making protection payments to private parties in mid-2001.

Dummy for Protection Payments to Police is a dummy equal 1 for firms in the same industry making protection payments to police in mid-2001.

Dummy for Protection Payments to Government Officials is a dummy equal 1 for firms in the same industry making protection payments to government officials in mid-2001.

Unofficial Payments is the sum of the Private Party, Police, and Governmental Officials dummies.

Payment for a Clean Environment is the proportion of sales the firm was willing to pay to operate in a clean business environment.

Proportion of Sales Sold with Trade Credit is the proportion of sales sold with trade credit in year $t-1$.

Proportion of Overdue Receivables is the amount of overdue receivables as a proportion of sales in year $t-1$.

\section{BASIC CHARACTERISTICS OF THE FIRM (REGRESSION CONTROLS)}

Age of Firm is the age of the firm since start date (either startup date in the case of new firms with no antecedents in state-owned enterprises or the date of the reorganization of a former state enterprise).

Reorganization is a dummy equal 1 if the firm was founded as a result of the reorganization of a pre-existing firm (i.e., if the firm was spun-off from another entity or founded on the basis of a split-up or merger). 
Spin-off is a dummy equal 1 if the firm spun off assets in year $t-1$.

Acquisition is a dummy equal 1 if the firm made an acquisition in year $t-1$.

City Size is the log of the population of the city where the firm is located.

County-Industry Employment Growth is the growth rate of employment in the firm's county (judet) and 2-digit NACE industry.

County-Industry Sales Growth is the growth rate of sales in the firm's county (judet) and 2digit NACE industry.

Industry Dummies include Heavy, Wholesale, Retail Trade of Food, Nonfood Retail Trade, Transportation, Light, and Other Services (1-digit CAEN level of aggregation).

Regional Dummies include South, Banat, West, Center, Moldova, and Bucharest. 


\section{REFERENCES}

Barlett, Will, and V. Bukvic, "Barriers to Small Business Growth in Slovenia," Working Paper based on Phare-ACE Project P97-8089-R, 2001.

Bilsen, Valentijn, and Jozef Konings, "Job Creation, Job Destruction, and Growth of Newly Established, Privatized, and State-Owned Enterprises in Transition Economies: Survey Evidence from Bulgaria, Hungary, and Romania," Journal of Comparative Economics, Vol. 26(3), 429445, September 1998.

Birch, David, Job Creation in America, New York: Free Press, 1987.

Bratkowski, Andrzej, Irena Grosfeld, and Jacek Rostowski, "Investment and Finance in De Novo Private Firms: Empirical Results from the Czech Republic, Hungary and Poland," Economics of Transition, Vol. 8(1), 101-116, 2000.

Center for Institutional Reform and the Informal Sector (IRIS), "Red Tape Analysis. Regulation and Bureaucracy in Romania," Bucharest, 2000.

Earle, John S., Saul Estrin, and Larisa Leshchenko, "Ownership Structures, Patterns of Control, and Enterprise Behavior in Russia," in S. Commander, Q. Fan, and M.E. Schaffer (eds.), Enterprise Restructuring and Economic Policy in Russia, Washington: World Bank-EDI, 1996.

Earle, John S., and Zuzana Sakova, "Entrepreneurship from Scratch," IZA Discussion Paper No. 79, 1999.

Earle, John S., and Zuzana Sakova, "Business Start-ups or Disguised Unemployment? Evidence on the Nature of Self-Employment from Transition Economies," Labour Economics, Vol. 7(5), 575-601, September 2000.

European Bank for Reconstruction and Development (EBRD), “Transition Report 1999: Ten Years of Transition," London: EBRD, 1999.

Heckman, James, Hidehiko Ichimura, Jeffrey Smith, and Petra Todd, "Characterizing Selection Bias Using Experimental Data," Econometrica, Vol. 66(5), 1017-1098, September 1998.

Hellman, Joel S., Geraint Jones, and Daniel Kaufmann, "Seize the State, Seize the Day: State Capture and Influence in Transition Economies," Journal of Comparative Economics, Vol. 31(4), 751-733, December 2003.

Johnson, Simon, and Gary Loveman, Starting Over in Eastern Europe: Entrepreneurship and Economic Renewal, Boston: Harvard Business School Press, 1995.

Johnson, Simon, John McMillan, and Christopher Woodruff, "Entrepreneurs and the Ordering of Institutional Reform," Economics of Transition, Vol. 8(1), 1-36, 2000.

Johnson, Simon, John McMillan, and Christopher Woodruff, "Property Rights and Finance," American Economic Review, Vol. 92(5), 1335-1356, December 2002.

Kornai, Janos, The Road to a Free Economy. Shifting from a Socialist System: The Example of Hungary, New York: W.W. Norton, 1990. 
Liedholm, Carl, and Donald C. Mead, Small Enterprises and Economics Development: The Dynamics of Micro and Small Enterprises, London and New York: Routledge Studies in Development Economics, 1999.

McMillan, John, and Christopher Woodruff, "Interfirm Relationships and Informal Credit in Vietnam," Quarterly Journal of Economics, Vol. 114(4), 1285-1320, 1999.

McMillan, John, and Christopher Woodruff, "The Central Role of Entrepreneurs in Transition Economies," Journal of Economic Perspectives, Vol. 16(3), 153-170, Summer 2002.

Meyer, Bruce D., "Natural and Quasi-Experiments in Economics," Journal of Business and Economic Statistics, Vol. 13(2), 151-162, 1995.

Morduch, Jonathan, "The Microfinance Promise," Journal of Economic Literature, Vol. XXXVII, 1569-1614, December 1999.

Murrell, Peter, "Evolution in Economics and in the Economic Reform of the Centrally Planned Economies," in Christopher C. Clague and Gordon Rausser (eds.), Emerging Market Economies in Eastern Europe, Cambridge: Basil Blackwell, 1992.

National Agency for Regional Development, The Private Sector of Small and Medium-Sized Enterprises in Romania: Report, Bucharest: National Agency for Regional Development, 2000.

Pissarides, Francesca, Miroslav Singer, and Jan Svejnar, "Objectives and Constraints of Entrepreneurs: Evidence from Small and Medium-Sized Enterprises in Russia and Bulgaria," Journal of Comparative Economics, Vol. 31(3), 503-531, September 2003.

Richter, Andrea, and Mark E. Schaffer, "The Performance of De Novo Private Firms in Russian Manufacturing," in S. Commander, Q. Fan, and M.E. Schaffer (eds.), Enterprise Restructuring and Economic Policy in Russia, Washington: World Bank-EDI, 1996.

Romanian Center for Small and Medium Size Enterprises, "The Private Sector of Small and Medium Size Enterprises in Romania. Annual Report 1997," Bucharest, 1998.

Schneider, Friedrich, "The Size and Development of the Shadow Economies of 22 Transition and 21 OECD Countries," IZA Discussion Paper No. 514, June 2002.

Winiecki, Jan, "The Polish Generic Private Sector in Transition: Developments and Characteristics," Europe-Asia Studies, Vol. 54(1), 5-29, 2002.

World Bank, Transition - The First Ten Years: Analysis and Lessons for Eastern Europe and the Former Soviet Union, Washington: World Bank, 2002. 
Figure 1: Average Annual Employment Growth

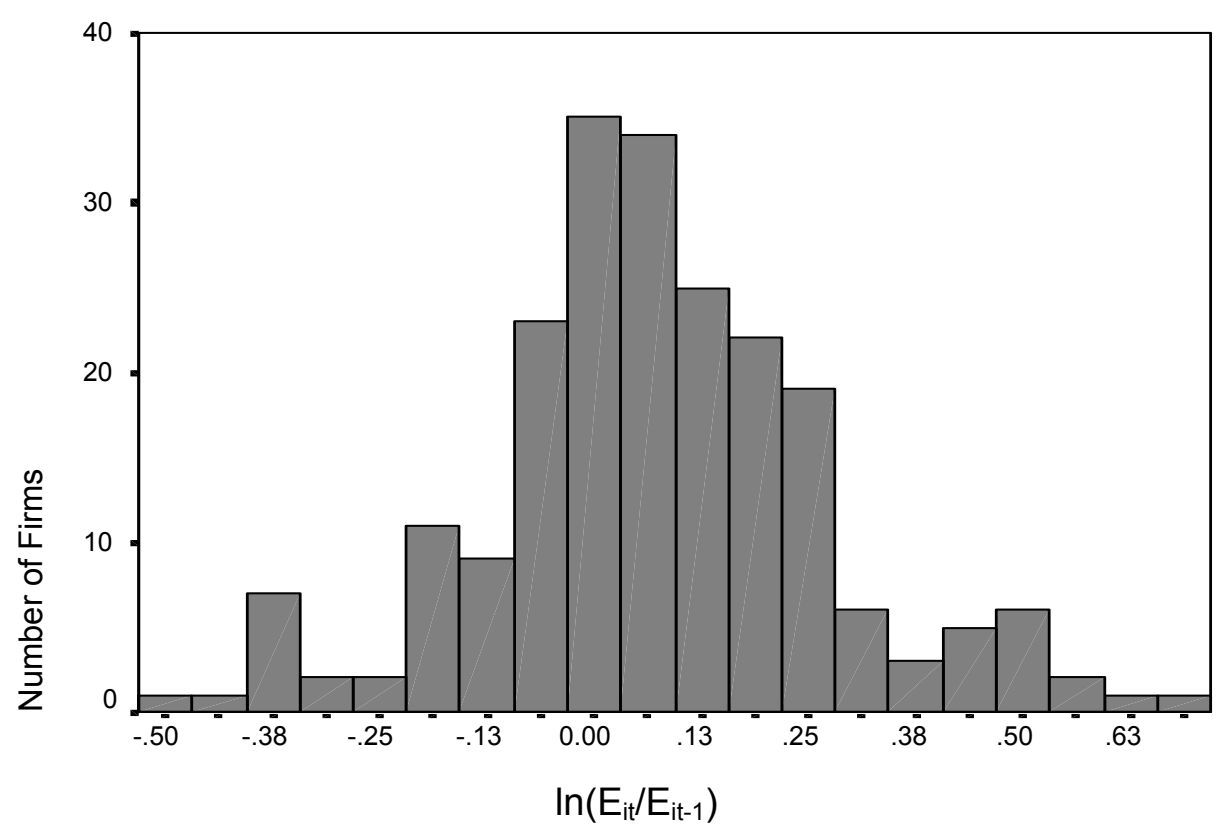

Figure 2: Average Annual Sales Growth

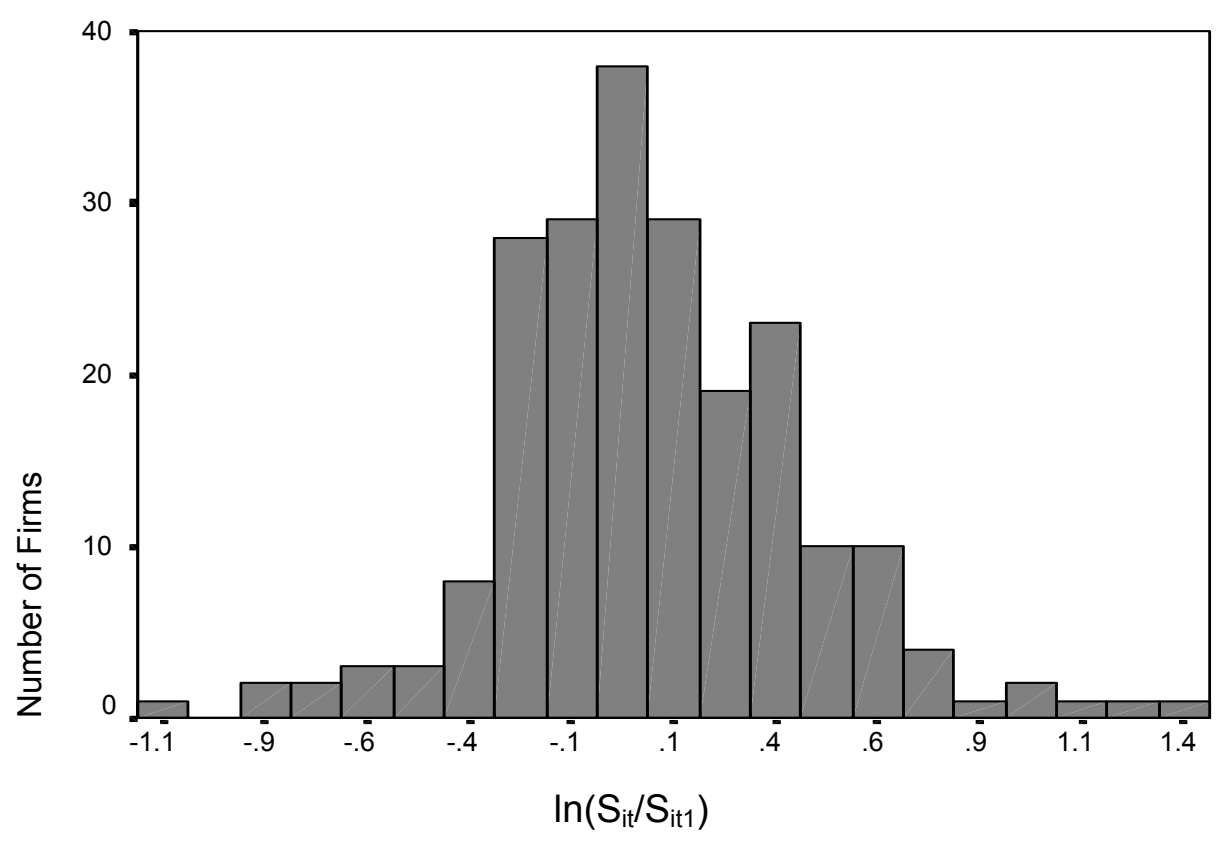


Figure 3: Managerial Opinions about Factors Creating the Largest Growth Constraints

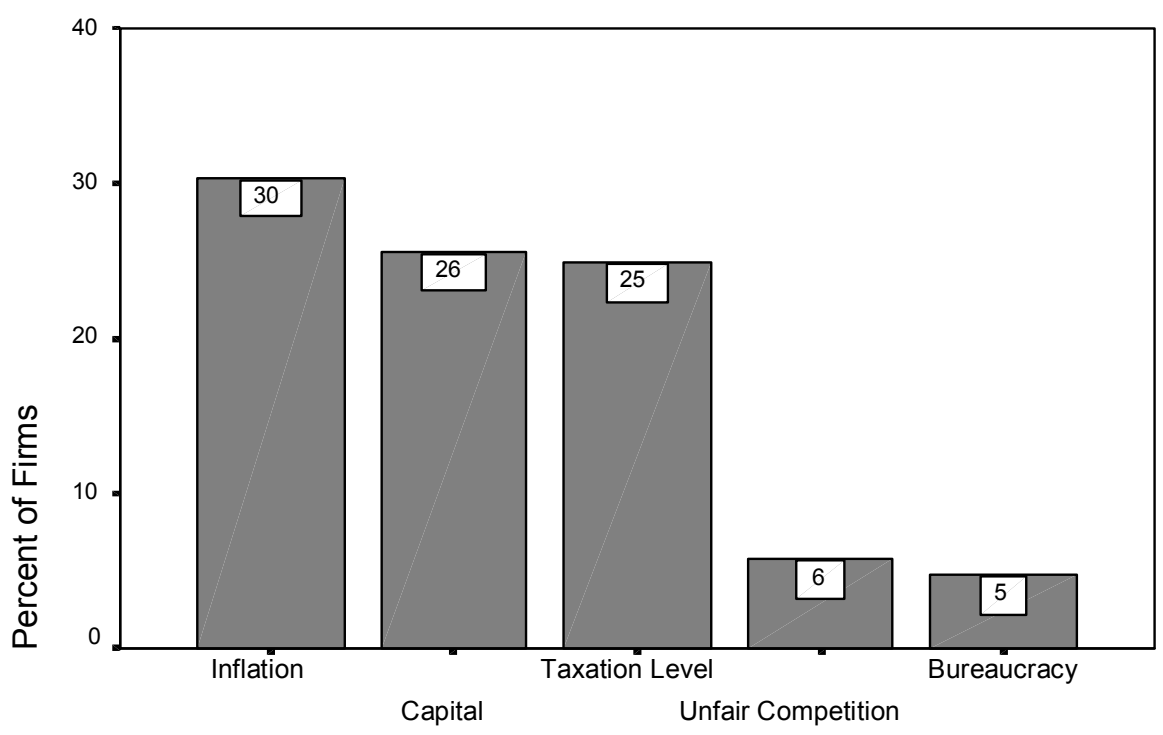

Table 1: Start Date (Year of Starting Operation or Last Major Reorganization)

\begin{tabular}{lcc}
\hline Year & $\begin{array}{c}\text { Number of } \\
\text { Firms }\end{array}$ & $\begin{array}{c}\text { Percent of } \\
\text { Firms }\end{array}$ \\
\hline 1989 & 4 & 1.4 \\
1990 & 3 & 1.0 \\
1991 & 32 & 10.8 \\
1992 & 41 & 13.8 \\
1993 & 34 & 11.4 \\
1994 & 64 & 21.5 \\
1995 & 25 & 8.4 \\
1996 & 25 & 8.4 \\
1997 & 26 & 8.8 \\
1998 & 25 & 8.4 \\
1999 & 18 & 6.1 \\
\hline
\end{tabular}

Note: $\mathrm{N}=297$. 
Table 2: Sample Composition

\begin{tabular}{|c|c|c|}
\hline & Number of Firms & Percent of Firms \\
\hline \multicolumn{3}{|l|}{ Region } \\
\hline Banat & 94 & 31.6 \\
\hline West & 64 & 21.5 \\
\hline Center & 54 & 18.2 \\
\hline Moldova & 17 & 5.7 \\
\hline South & 58 & 19.5 \\
\hline Bucharest & 10 & 3.4 \\
\hline \multicolumn{3}{|l|}{ Industry } \\
\hline Light Industry & 61 & 20.5 \\
\hline Heavy Industry & 27 & 9.1 \\
\hline Trade & 142 & 47.8 \\
\hline Transportation & 22 & 7.4 \\
\hline Other Services & 45 & 15.2 \\
\hline \multicolumn{3}{|c|}{ Number of Employees } \\
\hline $0-1$ & 9 & 3.3 \\
\hline $2-4$ & 52 & 18.9 \\
\hline $5-9$ & 86 & 31.3 \\
\hline $10-19$ & 64 & 23.3 \\
\hline $20-29$ & 20 & 7.3 \\
\hline $30-39$ & 8 & 2.9 \\
\hline $40-49$ & 11 & 4.0 \\
\hline $50-59$ & 7 & 2.5 \\
\hline $60-69$ & 5 & 1.8 \\
\hline $70+$ & 13 & 4.7 \\
\hline
\end{tabular}

Note: $\mathrm{N}=297$ for Region, 297 for Industry, and 275 for Number of Employees. Banat includes the counties of Caras Severin, Mehedinti, and Timisoara; West includes Arad and Cluj; Center includes Alba, Hunedoara, Mures, and Sibiu; Moldova includes Buzau, Galati, and lasi; South includes Arges, Constanta, and Dolj. Bucharest is the capital.

3-digit activities are grouped into 5 categories: Light Industry (food, beverages, textile, confection, shoes, leather, furniture, paper, publishing, construction services); Heavy Industry (chemical, rubber, plastic, metal parts, electric equipment, and instruments, recycling metallic materials, other products from minerals and metals); Trade (wholesale, retail food, retail non-food); Transportation; Other Services (accommodation and catering, real estate, repair, communication and education, information technology, unclassified service for firms and individuals). 
Table 3: Average Growth by Year

\begin{tabular}{lcccr}
\hline Year & \multicolumn{2}{c}{ Employment } & \multicolumn{2}{c}{ Sales } \\
\hline & $\begin{array}{c}\text { Average } \\
\text { Growth }\end{array}$ & $\mathrm{N}$ & $\begin{array}{c}\text { Average } \\
\text { Growth }\end{array}$ & $\mathrm{N}$ \\
\hline 1994 & 0.08 & 54 & 0.18 & 48 \\
1995 & 0.25 & 103 & 0.28 & 103 \\
1996 & 0.16 & 168 & 0.32 & 170 \\
1997 & 0.18 & 194 & 0.03 & 194 \\
1998 & 0.18 & 222 & 0.13 & 219 \\
1999 & 0.08 & 246 & 0.17 & 244 \\
2000 & -0.02 & 271 & 0.03 & 268 \\
2001 & 0.01 & 271 & n.a. & n.a. \\
\hline Average Annual & 0.07 & 238 & 0.11 & 248 \\
\hline Note: Fims are included from
\end{tabular}

Note: Firms are included from age 2 onwards. 
Table 4: Managerial Opinions about Growth Constraints

\begin{tabular}{|c|c|c|c|c|c|c|}
\hline \multirow{2}{*}{ Type of Factor } & \multirow{2}{*}{$\begin{array}{c}\text { All } \\
\text { Firms } \\
\end{array}$} & \multicolumn{2}{|c|}{ Growth Rate } & \multicolumn{3}{|c|}{ Firm Size } \\
\hline & & Slow & Fast & Micro & Small & Medium \\
\hline \multicolumn{7}{|l|}{ Finance } \\
\hline Lack of capital & 77.7 & 82.6 & 70.4 & 80.8 & 77.1 & 64.0 \\
\hline Lack of collateral & 41.5 & 35.8 & 45.4 & 37.6 & 43.8 & 36.0 \\
\hline Level of taxation & 91.1 & 92.7 & 88.9 & 92.8 & 86.7 & 96.0 \\
\hline \multicolumn{7}{|l|}{ Inputs } \\
\hline Hiring difficulties & 32.6 & 39.8 & 27.8 & 33.1 & 35.2 & 24.0 \\
\hline Difficulties finding premises & 18.4 & 22.9 & 17.6 & 23.2 & 18.1 & 8.0 \\
\hline Unreliable supplies & 11.0 & 15.6 & 5.6 & 13.6 & 11.4 & 8.0 \\
\hline \multicolumn{7}{|l|}{ Business Environment } \\
\hline Poor contract enforcement & 17.7 & 18.9 & 17.0 & 8.3 & 28.2 & 4.0 \\
\hline Admin. burden of taxation & 90.8 & 91.7 & 88.0 & 89.6 & 89.5 & 96.0 \\
\hline Bureaucratic interference & 33.3 & 35.2 & 29.6 & 35.5 & 32.4 & 28.0 \\
\hline Unfair competition & 46.8 & 49.1 & 37.4 & 41.9 & 51.0 & 41.7 \\
\hline Police protection payments & 2.5 & 4.6 & 0.9 & 5.6 & 0.0 & 0.0 \\
\hline Private protection payments & 1.8 & 2.8 & 0.9 & 3.2 & 1.0 & 0.0 \\
\hline \multicolumn{7}{|l|}{ Macroeconomic Factors } \\
\hline Inflation & 84.8 & 90.8 & 79.6 & 92.0 & 81.9 & 68.0 \\
\hline Low product demand & 37.2 & 47.2 & 29.9 & 45.2 & 32.7 & 16.0 \\
\hline Sample Size & 282 & & 7 & & 255 & \\
\hline \multicolumn{7}{|c|}{$\begin{array}{l}\text { Note: Respondents were asked to rate the degree to which they believed that the factor } \\
\text { constrained their own firm's growth. The degree is measured on a scale from } 1 \text { to } 5 \text {, where } 1 \\
\text { indicates not binding at all and } 5 \text { indicates extremely binding. In the table scores } 1-3 \text { are grouped } \\
\text { together as non-constraining or moderately constraining factors and scores 4-5 as "very } \\
\text { constraining" or "extremely binding" obstacles. "All firms" includes the entire sample; "slow" and } \\
\text { "fast" growth refer to below- and above-median employment growth, respectively; and "micro," } \\
\text { "small," and "medium" are defined as employment 0-9, 10-49, and 50-249, respectively. }\end{array}$} \\
\hline
\end{tabular}


Table 5: Incidence and Mean Size of Loans/Employment

\begin{tabular}{ccccr}
\hline Year & $\begin{array}{c}\text { Percentage Firms } \\
\text { Receiving Loans }\end{array}$ & $\begin{array}{c}\text { Mean Loan for } \\
\text { Recipient Firms }\end{array}$ & $\begin{array}{c}\text { Mean Loan for All } \\
\text { Firms }\end{array}$ & $\mathrm{N}$ \\
\hline 1994 & 25.0 & 1843.2 & 460.8 & 16 \\
1995 & 21.2 & 2218.6 & 470.6 & 33 \\
1996 & 27.9 & 3573.5 & 999.1 & 93 \\
1997 & 27.1 & 8481.4 & 2298.2 & 155 \\
1998 & 37.1 & 3847.5 & 1426.6 & 178 \\
1999 & 51.5 & 2659.4 & 1368.4 & 206 \\
2000 & 75.0 & 2793.9 & 2095.4 & 236 \\
2001 & 67.9 & 2222.6 & 1510.3 & 259 \\
\hline
\end{tabular}

Note: Loans are measured in USD.

Table 6: Incidence and Mean Size of Loans/Sales

\begin{tabular}{ccccc}
\hline Year & $\begin{array}{c}\text { Percentage Firms } \\
\text { Receiving Loans }\end{array}$ & $\begin{array}{c}\text { Mean Loan for } \\
\text { Recipient Firms }\end{array}$ & $\begin{array}{c}\text { Mean Loan for All } \\
\text { Firms }\end{array}$ & $\mathrm{N}$ \\
\hline 1994 & 19.1 & 0.184 & 0.035 & 21 \\
1995 & 22.5 & 0.291 & 0.065 & 40 \\
1996 & 26.8 & 0.365 & 0.098 & 97 \\
1997 & 25.8 & 0.959 & 0.247 & 163 \\
1998 & 35.3 & 0.562 & 0.200 & 187 \\
1999 & 51.5 & 0.595 & 0.306 & 206 \\
2000 & 74.4 & 0.898 & 0.668 & 238 \\
2001 & 66.0 & 0.436 & 0.289 & 256 \\
\hline
\end{tabular}

Note: Loans/Sales = USD of loans outstanding per USD of sales. Sales converted from ROL to USD using implicit price deflators and average year 2000 exchange rate of 21,700 ROL/USD. 
Table 7: Reinvestment Rates and Fiscal Facilities

\begin{tabular}{cccccccc}
\hline & \multicolumn{3}{c}{ Reinvestment Rates } & & \multicolumn{3}{c}{ Fiscal Facilities } \\
\cline { 2 - 3 } \cline { 6 - 7 } Year & $\begin{array}{c}\text { Rein- } \\
\text { vestment } \\
\text { Rate }\end{array}$ & $\begin{array}{c}\text { Percent } \\
\text { Firms } \\
\text { Reinvest- } \\
\text { ment>0 }\end{array}$ & $\mathrm{N}$ & & $\begin{array}{c}\text { Average } \\
\text { Number of } \\
\text { Facilities }\end{array}$ & $\begin{array}{c}\text { Percent } \\
\text { Firms } \\
\text { Receiving } \\
\text { Facilities }\end{array}$ & $\mathrm{N}$ \\
\hline 1992 & 55.0 & 75.0 & 4 & & n.a & n.a & n.a \\
1993 & 55.0 & 71.4 & 7 & & n.a & n.a & n.a. \\
1994 & 71.4 & 84.6 & 39 & & 1.8 & 10.3 & 39 \\
1995 & 62.1 & 75.0 & 80 & & 1.5 & 10.0 & 80 \\
1996 & 55.7 & 66.7 & 114 & & 1.4 & 7.9 & 114 \\
1997 & 56.3 & 69.1 & 178 & & 2.3 & 9.6 & 178 \\
1998 & 49.5 & 59.6 & 203 & & 2.0 & 8.9 & 203 \\
1999 & 42.0 & 50.4 & 228 & & 1.8 & 10.9 & 228 \\
2000 & 43.2 & 52.4 & 254 & & 1.4 & 11.0 & 254 \\
2001 & n.a & n.a & n.a & & 1.4 & 7.9 & 279 \\
\hline
\end{tabular}

Table 8: Characteristics of Entrepreneurs

\begin{tabular}{lc}
\hline Characteristics & $\begin{array}{c}\text { Average Percent } \\
\text { Ownership }\end{array}$ \\
\hline Female & 29.9 \\
Foreigner & 0.7 \\
Experience in Other Industry & 59.1 \\
High School Education & 30.3 \\
University Education & 49.0 \\
\hline
\end{tabular}

Note: $\mathbf{N}=2$ 293. Entrepreneur characteristics are weighted by the share ownership of each individual owner. Organizational owners are excluded. 
Table 9: Characteristics of Technical Assistance

\begin{tabular}{lc}
\hline & Percent of All Services \\
\hline Type & \\
Accounting & 8.6 \\
Legal & 7.8 \\
Business Plan Writing & 11.2 \\
Marketing & 15.5 \\
Use of New Technology & 11.6 \\
Information and Technology & 1.3 \\
Management & 9.9 \\
Training of Entrepreneurs & 15.1 \\
Training of Workers & 15.9 \\
Other & 3.0 \\
Financing Source & \\
Romanian Government & 2.2 \\
Romanian Foundation & 1.7 \\
Business Association & 13.0 \\
Paid by Firm & 50.4 \\
Foreign or International & 13.0 \\
Organization & 13.5 \\
USAID & 6.1 \\
Other Source & 20.1 \\
Service Provider & 29.7 \\
Local Governmental Agency & 2.1 \\
Central Governmental Agency & 4.4 \\
Romanian NGO & 6.1 \\
Romanian Firm or Freelancer & \\
International Organization & \\
Foreign Organization or Individual & \\
Other & 2.2 \\
\hline
\end{tabular}

Note: $\mathrm{N}=232$ for Types, 230 for Financing Sources, and 229 for

Service Providers. 
Table 10: Variables in the Regressions: Policy-Relevant Factors

\begin{tabular}{|c|c|c|}
\hline Variable & Mean & $\begin{array}{l}\text { Standard } \\
\text { Deviation }\end{array}$ \\
\hline \multicolumn{3}{|l|}{ Financial } \\
\hline Loans (1000 USD scaled by employment) & 1622.65 & 4674.47 \\
\hline Loans (scaled by sales) & 0.21 & 0.45 \\
\hline Fiscal Facilities & 0.18 & 0.61 \\
\hline Profit Reinvested & 50.85 & 45.20 \\
\hline Percentage of Materials Bought with Trade Credit & 37.00 & 32.62 \\
\hline \multicolumn{3}{|l|}{ Owner-Entrepreneur Characteristics } \\
\hline Female & 0.30 & 0.41 \\
\hline Foreigner & 0.01 & 0.06 \\
\hline Experience in Other Industry & 0.57 & 0.47 \\
\hline High School Education & 0.28 & 0.43 \\
\hline University Education & 0.48 & 0.47 \\
\hline Age & 40.80 & 8.55 \\
\hline \multicolumn{3}{|l|}{ Worker Education } \\
\hline Percent of Workers with High School & 54.23 & 34.72 \\
\hline Percent of Workers with University & 12.53 & 19.36 \\
\hline \multicolumn{3}{|l|}{ Technical Assistance } \\
\hline Number of Consulting and Training Services (TA) & 0.12 & 0.43 \\
\hline Number of Services Paid by Firm & 0.06 & 0.27 \\
\hline Number of Training Services & 0.04 & 0.20 \\
\hline Membership in a Business Association & 0.28 & \\
\hline TA from Government & 0.01 & 0.11 \\
\hline TA from NGOs & 0.02 & 0.13 \\
\hline TA from Foreign Source & 0.01 & 0.08 \\
\hline TA from International Organization & 0.03 & 0.17 \\
\hline \multicolumn{3}{|l|}{ Business Environment } \\
\hline Percent of Permits Not Obtained & 2.33 & 10.51 \\
\hline Average Number of Disputes per Year & 0.26 & 1.15 \\
\hline Payment for a Clean Environment & 0.08 & 0.15 \\
\hline Percent of Sales Sold with Trade Credit & 30.45 & 34.53 \\
\hline Overdue Receivables as Percentage of Sales & 14.23 & 21.32 \\
\hline Number of Permits in First Year of Operation & 0.42 & \\
\hline Number of Inspections in First Year of Operation & 0.21 & \\
\hline Unofficial Payments to Private Parties & 0.07 & \\
\hline Unofficial Payments to Police & 0.06 & \\
\hline Unofficial Payments to Government Officials & 0.28 & \\
\hline
\end{tabular}

Note: Standard deviations shown only for continuous variables. See Appendix for precise variable definitions. 
Table 11: Determinants of Growth: Base Specification

\begin{tabular}{|c|c|c|c|c|}
\hline & \multicolumn{2}{|c|}{ Employment Growth } & \multicolumn{2}{|c|}{ Sales Growth } \\
\hline & OLS & FE & OLS & FE \\
\hline \multicolumn{5}{|l|}{ Financial: } \\
\hline Loans & $\begin{array}{c}0.034 \\
(2.28)\end{array}$ & $\begin{array}{c}0.072 \\
(4.53)\end{array}$ & $\begin{array}{c}0.096 \\
(1.54)\end{array}$ & $\begin{array}{c}0.169 \\
(2.85)\end{array}$ \\
\hline Fiscal Facilities & $\begin{array}{r}0.047 \\
(2.18)\end{array}$ & $\begin{array}{r}0.080 \\
(1.92)\end{array}$ & $\begin{array}{c}0.048 \\
(1.32)\end{array}$ & $\begin{array}{c}0.033 \\
(0.41)\end{array}$ \\
\hline \multicolumn{5}{|l|}{ Entrepreneur Characteristics: } \\
\hline Experience in Other Industry & $\begin{array}{c}0.044 \\
(1.69)\end{array}$ & $\begin{array}{c}-0.002 \\
(-0.01)\end{array}$ & $\begin{array}{c}0.101 \\
(1.54)\end{array}$ & $\begin{array}{c}-0.101 \\
(-0.16)\end{array}$ \\
\hline Age & $\begin{array}{c}-0.023 \\
(-2.33)\end{array}$ & $\begin{array}{c}0.031 \\
(0.74)\end{array}$ & $\begin{array}{l}-0.073 \\
(-2.80)\end{array}$ & $\begin{array}{l}-0.079 \\
(-0.82)\end{array}$ \\
\hline $\mathrm{Age}^{2}$ & $\begin{array}{c}0.000 \\
(2.02)\end{array}$ & $\begin{array}{l}-0.000 \\
(-1.03)\end{array}$ & $\begin{array}{c}0.000 \\
(2.55)\end{array}$ & $\begin{array}{c}0.001 \\
(0.92)\end{array}$ \\
\hline \multicolumn{5}{|l|}{ Education: } \\
\hline High School & $\begin{array}{l}-0.004 \\
(0.11)\end{array}$ & $\begin{array}{c}-0.007 \\
(-0.03)\end{array}$ & $\begin{array}{c}0.018 \\
(0.21)\end{array}$ & $\begin{array}{c}0.580 \\
(0.91)\end{array}$ \\
\hline University & $\begin{array}{r}0.027 \\
(0.66)\end{array}$ & $\begin{array}{c}0.245 \\
(0.64)\end{array}$ & $\begin{array}{r}0.001 \\
(0.01)\end{array}$ & $\begin{array}{c}0.624 \\
(0.79)\end{array}$ \\
\hline Foreign & $\begin{array}{c}-0.207 \\
(-0.42)\end{array}$ & $\begin{array}{c}0.999 \\
(1.45)\end{array}$ & $\begin{array}{c}0.085 \\
(0.15)\end{array}$ & $\begin{array}{l}1.110 \\
(0.86)\end{array}$ \\
\hline Female & $\begin{array}{l}-0.025 \\
(-0.82)\end{array}$ & $\begin{array}{c}-0.284 \\
(-1.10)\end{array}$ & $\begin{array}{c}-0.002 \\
(-0.03)\end{array}$ & $\begin{array}{l}-0.118 \\
(-1.39)\end{array}$ \\
\hline \multicolumn{5}{|l|}{ Worker Education: } \\
\hline High School & $\begin{array}{c}0.000 \\
(1.47)\end{array}$ & & $\begin{array}{c}0.000 \\
(0.53)\end{array}$ & \\
\hline University & $\begin{array}{l}-0.000 \\
(-0.33)\end{array}$ & & $\begin{array}{c}-0.002 \\
(-0.91)\end{array}$ & \\
\hline Technical Assistance Number & $\begin{array}{c}0.039 \\
(0.90)\end{array}$ & $\begin{array}{c}-0.021 \\
(-0.39)\end{array}$ & $\begin{array}{c}0.040 \\
(0.76)\end{array}$ & $\begin{array}{l}-0.037 \\
(-0.33)\end{array}$ \\
\hline $\mathrm{N}$ & \multicolumn{2}{|c|}{1031} & \multicolumn{2}{|c|}{789} \\
\hline$R^{2}$ & 0.100 & 0.185 & 0.103 & 0.100 \\
\hline
\end{tabular}

Note: $T$-statistics based on robust standard errors are in parentheses. Loan amount (in USD) is scaled by employment in the employment growth equation and by USD value of sales in the sales growth equation. Though not reported here, the fixed-effects regressions include employment (sales) growth in the county-industry, dummies for acquisitions and spin-offs, two size-category dummies, and year dummies. Besides these, the OLS regressions also include firm age, city population, a dummy for reorganized firms, six sector dummies, and five regional dummies. $R^{2}=R^{2}$-within for fixed-effects regressions. 


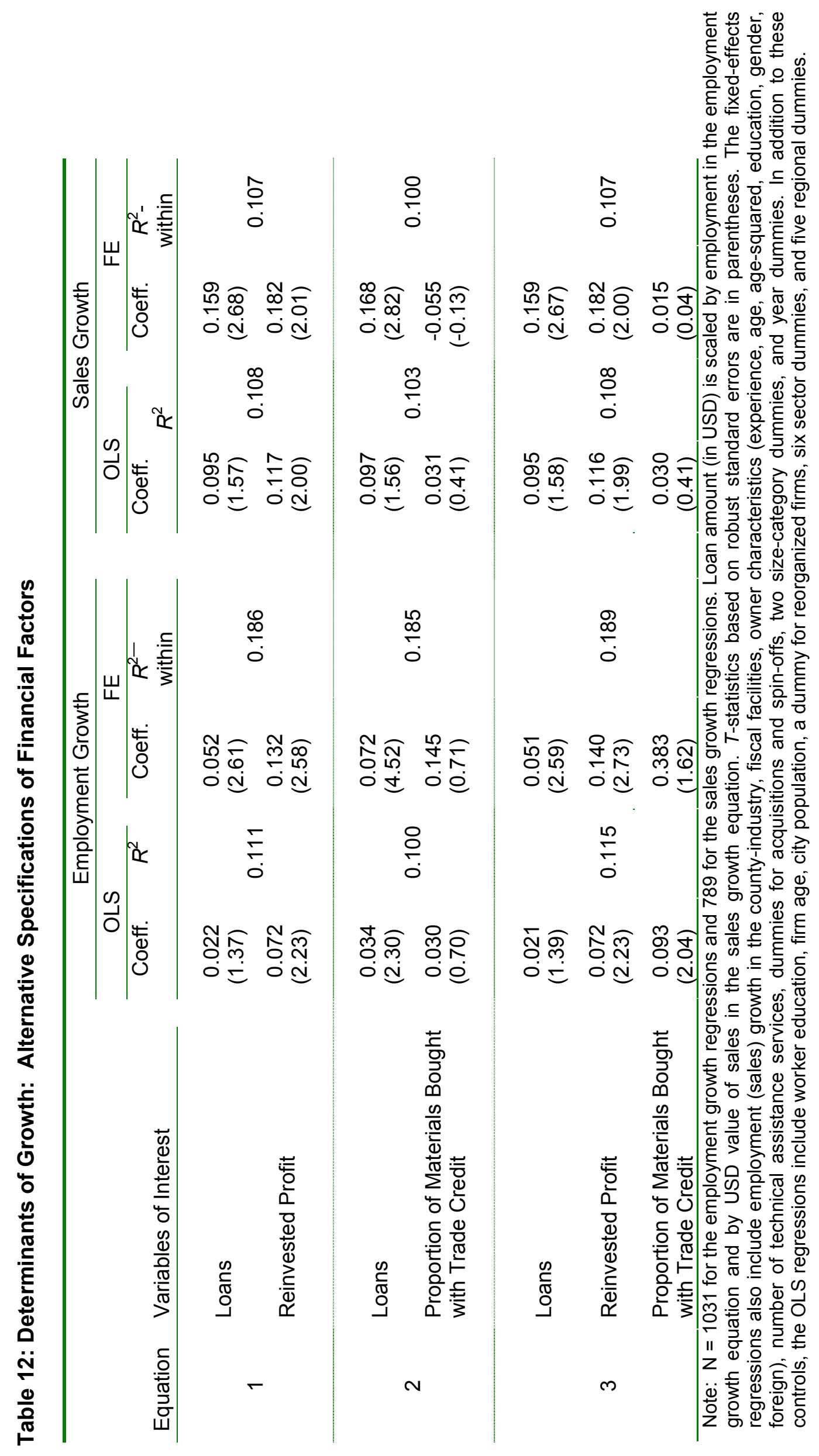




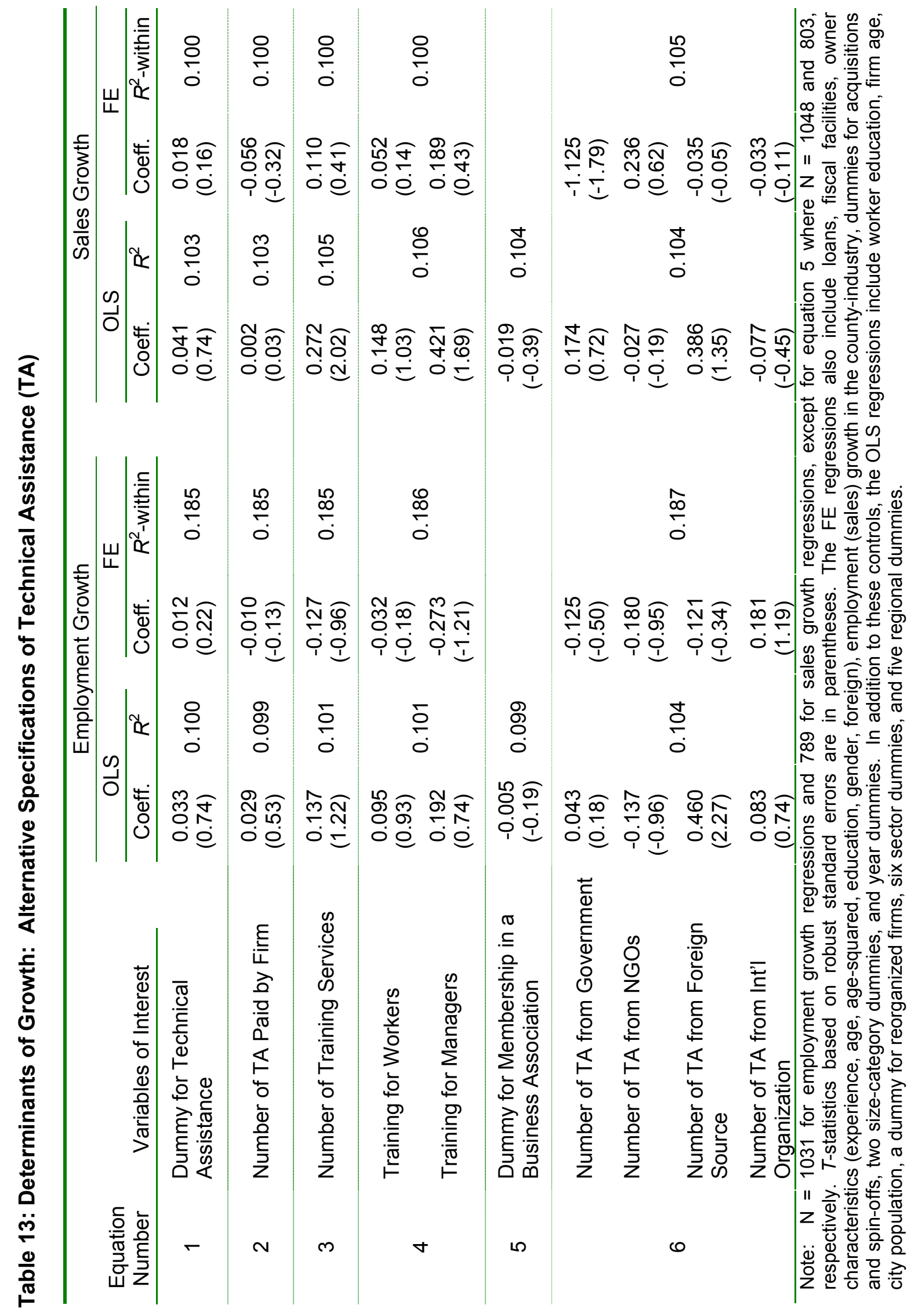




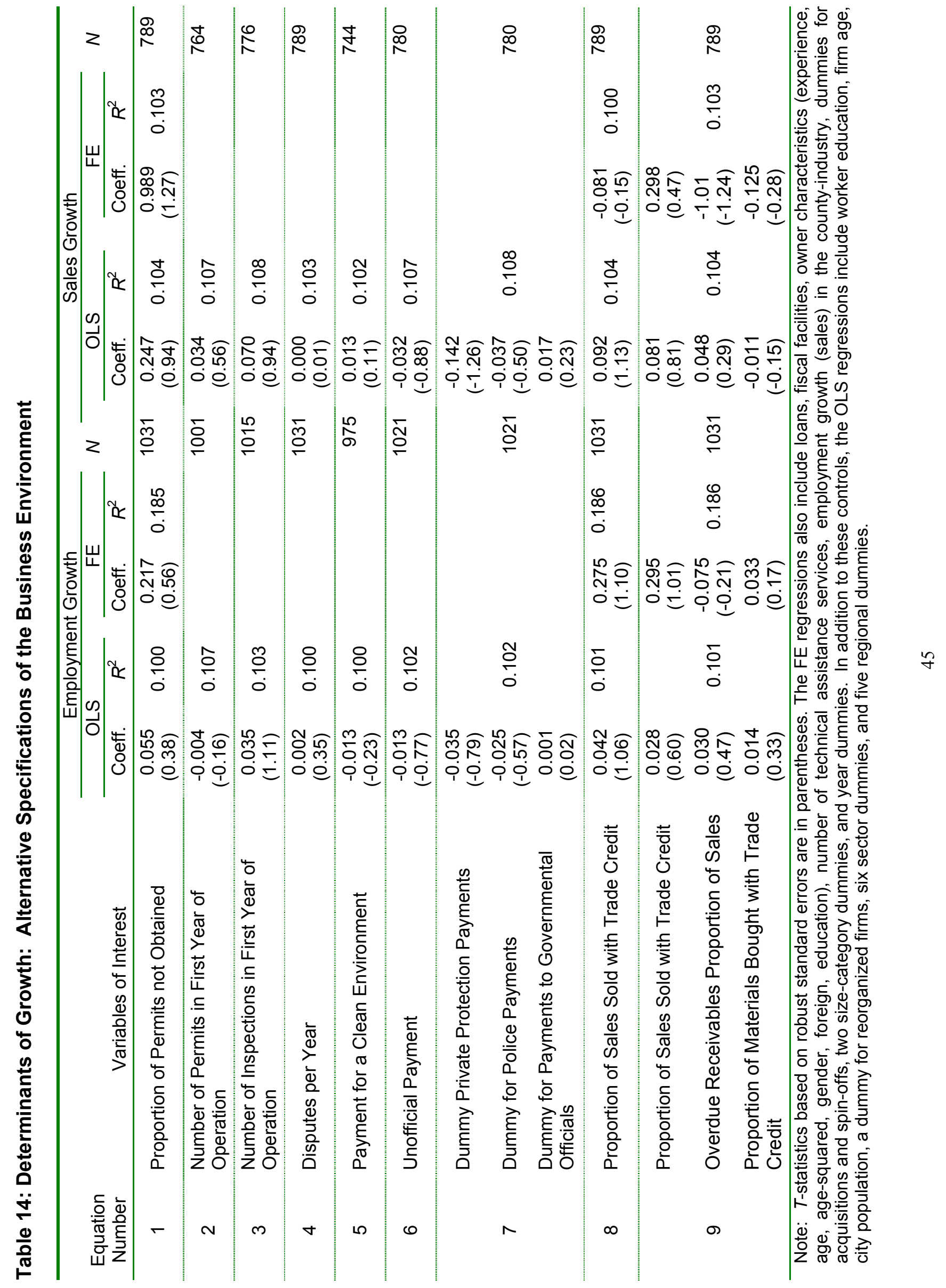




\section{DAVIDSON INSTITUTE WORKING PAPER SERIES - Most Recent Papers}

The entire Working Paper Series may be downloaded free of charge at: www.wdi.bus.umich.edu

CURRENT AS OF 5/24/04

\begin{tabular}{|c|c|c|}
\hline Publication & Authors & Date \\
\hline $\begin{array}{l}\text { No. 702: What Makes Small Firms Grow? Finance, Human Capital, } \\
\text { Technical Assistance, and the Business Environment in Romania }\end{array}$ & $\begin{array}{l}\text { J. David Brown, John S. Earle } \\
\text { and Dana Lup }\end{array}$ & May 2004 \\
\hline $\begin{array}{l}\text { No. 701: The Effects of Multiple Minimum Wages Throughout the } \\
\text { Labor Market }\end{array}$ & $\begin{array}{l}\text { T. H. Gindling and Katherine } \\
\text { Terrell }\end{array}$ & May 2004 \\
\hline No. 700: Minimum Wages, Inequality and Globalization & $\begin{array}{l}\text { T. H. Gindling and Katherine } \\
\text { Terrell }\end{array}$ & May 2004 \\
\hline No. 699: Self-Selection and Earnings During Volatile Transition & Ralitza Dimova and Ira Gang & May 2004 \\
\hline No. 698: Ecology and Violence: The Environmental Dimensions of War & $\begin{array}{l}\text { Timothy L. Fort and Cindy A. } \\
\text { Schipani }\end{array}$ & May 2004 \\
\hline $\begin{array}{l}\text { No. 697: Russian Cities in Transition: The Impact of Market Forces in } \\
\text { the 1990s }\end{array}$ & Ira N. Gang and Robert C. Stuart & May 2004 \\
\hline $\begin{array}{l}\text { No. 696: Firm Ownership and Internal Labor Practices in a Transition } \\
\text { Economy: An Exploration of Worker Skill Acquisition in Vietnam }\end{array}$ & Jed Friedman & May 2004 \\
\hline No. 695: The Unanticipated Effects of Insider Trading Regulation & $\begin{array}{l}\text { Art A. Durnev and Amrita S. } \\
\text { Nain }\end{array}$ & May 2004 \\
\hline $\begin{array}{l}\text { No. 694: Volatile Interest Rates, Volatile Crime Rates: A New } \\
\text { Argument for Interest Rate Smoothing }\end{array}$ & Garett Jones and Ali M. Kutan & May 2004 \\
\hline $\begin{array}{l}\text { No. } 693 \text { Money Market Liquidity under Currency Board - Empirical } \\
\text { Investigations for Bulgaria }\end{array}$ & $\begin{array}{l}\text { Petar Chobanov and Nikolay } \\
\text { Nenovsky }\end{array}$ & May 2004 \\
\hline $\begin{array}{l}\text { No. 692: Credibility and Adjustment: Gold Standards Versus Currency } \\
\text { Boards }\end{array}$ & $\begin{array}{l}\text { Jean Baptiste Desquilbet and } \\
\text { Nikolay Nenovsky }\end{array}$ & May 2004 \\
\hline $\begin{array}{l}\text { No. 691: Impact of Cross-listing on Local Stock Returns: Case of } \\
\text { Russian ADRs }\end{array}$ & Elena Smirnova & May 2004 \\
\hline $\begin{array}{l}\text { No. 690: Executive Compensation, Firm Performance, and State } \\
\text { Ownership in China:Evidence from New Panel Data }\end{array}$ & Takao Kato and Cheryl Long & May 2004 \\
\hline $\begin{array}{l}\text { No. 689: Diverging Paths: Transition in the Presence of the Informal } \\
\text { Sector }\end{array}$ & Maxim Bouev & May 2004 \\
\hline $\begin{array}{l}\text { No. 688: What Causes Bank Asset Substitution in Kazakhstan? } \\
\text { Explaining Currency Substitution in a Transition Economy }\end{array}$ & Sharon Eicher & May 2004 \\
\hline $\begin{array}{l}\text { No. 687: Financial Sector Returns and Creditor Moral Hazard: Evidence } \\
\text { from Indonesia, Korea and Thailand }\end{array}$ & $\begin{array}{l}\text { Ayse Y. Evrensel and Ali M. } \\
\text { Kutan }\end{array}$ & May 2004 \\
\hline $\begin{array}{l}\text { No. 686: Instability in Exchange Rates of the World Leading } \\
\text { Currencies: Implications of a Spatial Competition Model }\end{array}$ & $\begin{array}{l}\text { Dirk Engelmann, Jan Hanousek } \\
\text { and Evzen Kocenda }\end{array}$ & May 2004 \\
\hline $\begin{array}{l}\text { No. 685: Corporate Spinoffs, Privatization, and Performance in } \\
\text { Emerging Markets }\end{array}$ & $\begin{array}{l}\text { Jan Svejnar, Evzen Kocenda and } \\
\text { Jan Hanousekf }\end{array}$ & May 2004 \\
\hline $\begin{array}{l}\text { No. 684: CPI Bias and Real Living Standards in Russia During the } \\
\text { Transition }\end{array}$ & $\begin{array}{l}\text { John Gibson, Steven Stillman and } \\
\text { Trinh Le }\end{array}$ & May 2004 \\
\hline $\begin{array}{l}\text { No. 683: Mission Implausible III: Measuring the Informal Sector in a } \\
\text { Transition Economy using Macro Methods }\end{array}$ & Jan Hanousek and Filip Palda & May 2004 \\
\hline $\begin{array}{l}\text { No. 682: The Other Side of the Moon: The Data Problem in Analyzing } \\
\text { Growth Determinants }\end{array}$ & $\begin{array}{l}\text { Jan Hanousek, Dana Hajkova and } \\
\text { Randall K. Filer }\end{array}$ & May 2004 \\
\hline $\begin{array}{l}\text { No. 681: Consumers' Opinion of Inflation Bias Due to Quality } \\
\text { Improvements }\end{array}$ & $\begin{array}{l}\text { Jan Hanousek and Randall K. } \\
\text { Filer }\end{array}$ & May 2004 \\
\hline $\begin{array}{l}\text { No. 680: IMF-Related Announcements, Fundamentals, and Creditor } \\
\text { Moral Hazard: A Case Study of Indonesia }\end{array}$ & $\begin{array}{l}\text { Ayşe Y. Evrensel and Ali M. } \\
\text { Kutan }\end{array}$ & May 2004 \\
\hline No. 679: Privatization Matters: Bank Efficiency in Transition Countries & $\begin{array}{l}\text { John P. Bonin, Iftekhar Hasan and } \\
\text { Paul Wachtel }\end{array}$ & Apr. 2004 \\
\hline $\begin{array}{l}\text { No. 678: Does Market Liberalisation Reduce Gender Discrimination? } \\
\text { Econometric Evidence from Hungary, 1986-1998 }\end{array}$ & $\begin{array}{l}\text { Dean Jolliffe and Nauro F. } \\
\text { Campos }\end{array}$ & Apr. 2004 \\
\hline $\begin{array}{l}\text { No. 677: Governance and Performance of Microfinance Institutions in } \\
\text { Central And Eastern Europe and the Newly Independent States }\end{array}$ & Valentina Hartarska & Apr. 2004 \\
\hline $\begin{array}{l}\text { No. 676: Equilibrium Exchange Rates in the Transition: The Tradable } \\
\text { Price-Based Real Appreciation and Estimation Uncertainty }\end{array}$ & $\begin{array}{l}\text { Balázs Égert and Kirsten } \\
\text { Lommatzsch }\end{array}$ & Apr. 2004 \\
\hline
\end{tabular}

